Environmental Sciences Division

\title{
POTENTIAL SUPPLY AND COST OF BIOMASS FROM ENERGY CROPS IN THE TVA REGION
}

R. L. Graham and M. E. Downing

Environmental Sciences Division

Publication No. 4306

Date Published: April 1995

Prepared for the

Office of Transportation Technologies

Biofuels Systems Division

and the

Office of Utility Technologies

Solar Thermal and Biomass Power Division

EB 2413010

\section{Prepared by}

OAK RIDGE NATIONAL LABORATORY

Oak Ridge, Tennessee 37831-6285

managed by

MARTIN MARIETTA ENERGY SYSTEMS, INC.

for the

U.S. DEPARTMENT OF ENERGY

under contract DE-AC05-84OR21400

DISTABUTION OF RAIS DOCUMENT IS UNLMMTEO

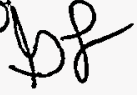




\section{DISCLAIMER}

This report was prepared as an account of work sponsored by an agency of the United States Government. Neither the United States Government nor any agency thereof, nor any of their employees, make any warranty, express or implied, or assumes any legal liability or responsibility for the accuracy, completeness, or usefulness of any information, apparatus, product, or process disclosed, or represents that its use would not infringe privately owned rights. Reference herein to any specific commercial product, process, or service by trade name, trademark, manufacturer, or otherwise does not necessarily constitute or imply its endorsement, recommendation, or favoring by the United States Government or any agency thereof. The views and opinions of authors expressed herein do not necessarily state or reflect those of the United States Government or any agency thereof. 


\section{DISCLAIMER}

Portions of this document may be illegible in electronic image products. Images are produced from the best available original document. 
CONTENTS

Page

LIST OF FIGURES $\ldots \ldots \ldots \ldots \ldots \ldots \ldots \ldots \ldots \ldots \ldots \ldots \ldots \ldots$

LIST OF TABLES $\ldots \ldots \ldots \ldots \ldots \ldots \ldots \ldots \ldots \ldots \ldots \ldots \ldots \ldots$

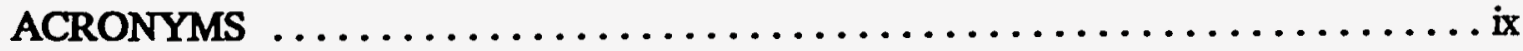

ACKNOWLEDGMENTS $\ldots \ldots \ldots \ldots \ldots \ldots \ldots \ldots \ldots \ldots \ldots \ldots \ldots \ldots \ldots$

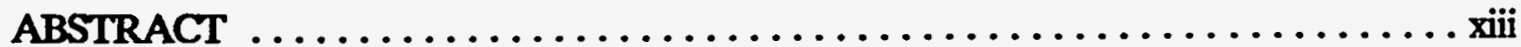

1. INTRODUCTION $\ldots \ldots \ldots \ldots \ldots \ldots \ldots \ldots \ldots \ldots \ldots \ldots \ldots \ldots \ldots$

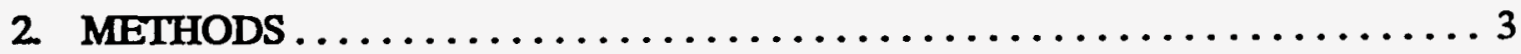

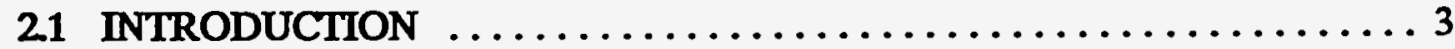

2.2 CHARACTERIZE LAND BASE AND CROPS_STAGE $1 \ldots \ldots \ldots \ldots \ldots 7$

23 DEVELOP CROP MANAGEMENT AND PRODUCTION COSTS STAGE $2 \ldots \ldots \ldots \ldots \ldots \ldots \ldots \ldots \ldots$

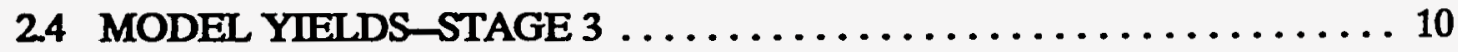

2.5 CALCULATE BREAK-EVEN PRICE FOR BIOMASS-STAGE $4 \ldots \ldots$. 12

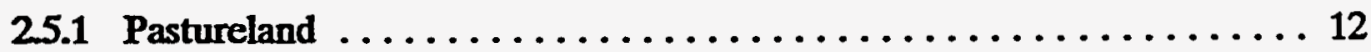

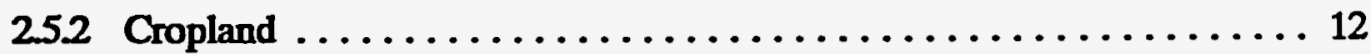

26 CALCULATE REGIONAL COST AND SUPPLY OF

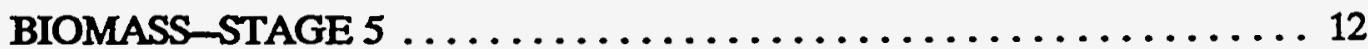

3. RESULTS AND DISCUSSION $\ldots \ldots \ldots \ldots \ldots \ldots \ldots \ldots \ldots \ldots \ldots \ldots \ldots$

3.1 YIELDS, PRODUCTION COSTS, AND FARM-GATE PRICES . . . . . . 13

3.1.1 SRWC ........................... 13

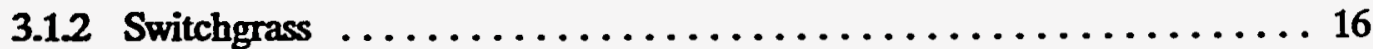

3.2 REGIONAL SUPPLY PATTERNS $\ldots \ldots \ldots \ldots \ldots \ldots \ldots \ldots \ldots \ldots \ldots$

3.2.1 Projected SRWC Supplies at Current Biomass Yield Level . . . . . . . 24

3.22 Projected Switchgrass Supplies at Current Biomass Yield Level . . . . . 25

3.2 .3 Projected SRWC and Switchgrass Supplies at a 25\% Higher

Yield Level . . . . . . . . . . . . . . . . . . . . . . 26

3.3 PROJECTED REGIONAL SUPPLY CURVES . . . . . . . . . . . 26

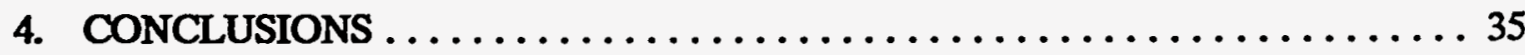

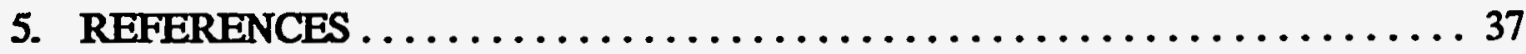




\section{LIST OF FIGURES}

Figure

Page

1 Percentage of the county land base in crops or pasture $\ldots \ldots \ldots \ldots \ldots$

2 Five-stage approach used to develop maps of potential biomass supplies in the TVA region and to create regional biomass supply curves $\ldots \ldots \ldots \ldots 6$

3 Subregions in the TVA region $\ldots \ldots \ldots \ldots \ldots \ldots \ldots \ldots \ldots \ldots$

4 Amount of SRWC wood feedstock (in MBtu) that could potentially be produced in the TVA region counties at a farm-gate price of less than $\$ 2.00 / \mathbf{M B t u}$, less than $\$ 250 / \mathbf{M B t u}$, and less than $\$ 3.00 / \mathrm{MBtu} \ldots \ldots \ldots \ldots . .22$

5 Amount of switchgrass feedstock (in MBtu) that could potentially be produced in the TVA region counties at a farm-gate price of less than $\$ 2.00 / \mathrm{MBtu}$, less than $\$ 2.50 / \mathrm{MBtu}$, and less than $\$ 3.00 / \mathrm{MBtu} \ldots \ldots \ldots \ldots 23$

6 Amount of SRWC wood feedstock (in MBtu) that could potentially be produced in the TVA region counties at a farm-gate price of less than $\$ 2.00 / \mathrm{MBtu}$, less than $\$ 2.50 / \mathrm{MBtu}$, and less than $\$ 3.00 / \mathrm{MBtu}$ if current SRWC yields were increased $25 \%$. . . . . . . . . . . . . . . 27

7 Amount of switchgrass feedstock (in MBtu) that could potentially be produced in the TVA region counties at a farm-gate price of less than $\$ 2.00 / \mathrm{MBtu}$, less than $\$ 2.50 / \mathrm{MBtu}$, and less than $\$ 3.00 / \mathrm{MBtu}$ if current switchgrass yields were increased $25 \% \ldots \ldots \ldots \ldots \ldots \ldots$

8 Regionwide supply curves for SRWC wood feedstock in units of energy (MBtu), assuming current yield and 25\% increased yield . . . . . . . . . 29

9 Regionwide supply curves for switchgrass feedstock in units of energy (MBtu), assuming current yield and $25 \%$ increased yield ........... 30

10 Regionwide supply curves for SRWC wood feedstock in units of biomass (tons), assuming current yield and $25 \%$ increased yield . . . . . . . . . 32

11 Regionwide supply curves for switchgrass feedstock in units of biomass (tons), assuming current yield and $25 \%$ increased yield . . . . . . . . . 33 


\section{LIST OF TABLES}

Table

Page

1 Projected land rents used to calculate farm-gate prices of SRWC

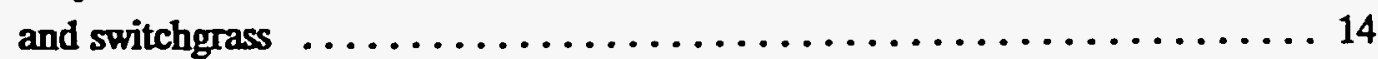

2 SRWC production costs and current annual yield by land use and soil

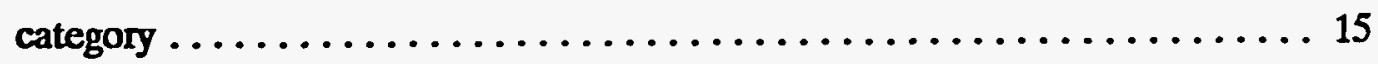

3 Projected SRWC farm-gate prices by subregion and soil category . . . . . . 17

4 Projected switchgrass yield by subregion and soil category $\ldots \ldots \ldots \ldots \ldots 18$

5 Projected switchgrass production costs by subregion and soil category . . . . . 20

6 Estimated switchgrass farm-gate prices by subregion and soil category . . . . 21 


\section{ACRONYMS}

ARS Agricultural Research Service

EPIC Erosion Productivity Impact Calculator

MLRA Major Land Resource Areas

NRI National Resources Inventory

OTA Office of Technology Assessment

SCS Soil Conservation Service

SRWC Short-rotation Woody Crops

TVA Tennessee Valley Authority

USDA U.S. Department of Agriculture

UT The University of Tennessee 


\section{ACKNOWLEDGMENTS}

This report was prepared by the Biofuels Feedstock Development Program, Environmental Sciences Division, Oak Ridge National Laboratory, Oak Ridge, Tennessee 37831, managed by Martin Marietta Energy Systems, Inc., under contract DE-AC05$840 R 21400$ with the U.S. Department of Energy. Publication No. 4306, ESD, ORNL. 
xii 


\begin{abstract}
The economic and supply structures of energy crop markets have not been established. Establishing the likely price and supply of energy crop biomass in a region is a complex task because biomass is not an established commodity as are oil, natural gas, and coal. In this study, the cost and supply of short-rotation woody crop (SRWC) and switchgrass biomass for the Tennessee Valley Authority (TVA) region-a 276-county area that includes portions of 11 states in the southeastern United States-are projected. Projected prices and quantities of biomass are assumed to be a function of the amount and quality of crop and pasture land available in a region, expected energy crop yields and production costs on differing soils and land types, and the profit that could be obtained from current conventional crop production on these same lands. Results include the supply curves of SRWC and switchgrass biomass that are projected to be available from the entire region, the amount and location of crop and pasture land that would be used, and the conventional agricultural crops that would be displaced as a function of energy crop production.

Finally, the results of sensitivity analysis on the projected cost and supply of energy crop biomass are shown. In particular, the separate impacts of varying energy crop production costs and yields, and interest rates are examined.
\end{abstract}




\section{INTRODUCTION}

The goal of this project was to provide the Tennessee Valley Authority (TVA) with information with which to evaluate land base capabilities in terms of supplying sufficient biomass from energy crops at a price that would allow it to compete with coal. Specifically, the objective of this research was to determine how much biomass could be grown, where it could be grown, how much it would cost to produce, and what the price would be.

The potential land base for energy crop production was defined by TVA and encompassed the 201 TVA service counties plus 75 additional counties that were within a 75-mile radii of existing TVA coal-fired power plants. The energy crops considered in this analysis were SRWCs (short-rotation woody crops) and switchgrass. SRWCs are trees grown at tight spacings with weed control and some fertilizer application. The wood and bark of the boles and branches are harvested at 6- to 10-year rotations, whereas the leaves, stumps, and roots remain on the site (Wright et al. 1992a). A variety of hardwood tree species (hybrid poplar, sweetgum, sycamore, and black locust) was considered in the analysis. Switchgrass (Panicum varigatum) is a native perennial tallgrass-prairie species. It is a $\mathrm{C}_{4}$ plant and a bunchgrass. Switchgrass can take several years to become established. Stands are ready for harvest during their second growing season and annually thereafter. Switchgrass is harvested and baled like any other hay crop and, like other grasses, provides good erosion control. For maximum production, it requires some fertilizer application. Four production scenarios were examined in the analysis: (1) SRWC production on agricultural land, assuming current expected SRWC and conventional crop yields; (2) switchgrass production on agricultural land, assuming current expected switchgrass and conventional crop yields; (3) SRWC production on agricultural land, assuming current conventional crop yields and a 25\% in SRWC yields; and (4) switchgrass production on agricultural land, assuming current conventional crop yields and a $25 \%$ increase in switchgrass yields. 


\section{METHODS}

\section{INTRODUCTION}

Because energy crops ${ }^{1}$ are not currently grown in the TVA region, organized markets for SRWC and switchgrass feedstocks do not exist. Consequently, quantity and price information for biomass energy crop feedstock must be modeled. The model of energy crop price and supply used in this analysis is based on the assumption that farmers will convert their agricultural land to biomass production when the profit received from producing biomass meets or exceeds current profit margins received from producing conventional agricultural crops or using their land for pasture [Equation (1)].

$$
\left(\mathrm{YLD}_{c}^{*} \mathrm{PRICE}_{c}\right)-\mathrm{COST}_{c}=\left(\mathrm{YLD}_{w}^{*} \mathrm{BEP}\right)-\mathrm{COST}_{w},
$$

where

$c=$ conventional crop displaced by the energy crop,

$w \quad=$ type of energy crop (switchgrass or SRWC species),

$\mathrm{YLD}_{c}=$ yield expected for conventional crop $c$ (bushels or bales per acre),

PRICE $_{c}=$ expected market price of the conventional crop $c$ (\$ per bushel or bale),

$\mathrm{COST}_{c}=$ cost of producing conventional crop $c$ (\$ per acre),

$\mathrm{YLD}_{w} \quad=$ annual harvested yield of energy crop $w$ (tons per acre per year),

BEP = break-even price of harvested energy crop biomass ( $\$$ per ton),

$\operatorname{COST}_{w}=$ annual cost of producing energy crop $w\left(\$\right.$ per acre) ${ }^{2}$

The left side of the equation may be considered land rent or returns to land and management from growing conventional crops on cropland or maintaining pastureland in pasture production. Agricultural commodity payments or other government subsidies are not included in this land rent because existing programs are likely to change in the near future.

The right side of the equation, along the same line, is the land rent received from growing biomass crops on the same land. If all other variables can be quantified, the break-even price can be solved.

${ }^{1}$ Switchgrass is grown as a forage crop but not an energy crop within the region.

${ }^{2}$ The cost of producing the energy or conventional crop does not include the cost or value of the land, which is presumed to be the same regardless of the intended use. 
For cropland, the farm-gate price of biomass-the price a utility would have to pay a farmer for harvested biomass (not transported)-was assumed to be the same as the biomass break-even price associated with the most profitable dominant conventional crop that could be grown on the land. Using the break-even price associated with the most profitable crop rather than the actually grown crop provided some assurance that the farm-gate prices were not underestimated. Dominant conventional crops (such as corn, soybeans, wheat, and cotton) were used to define the farm-gate price under the assumption that these crops, rather than minor crops such as barley, rye, and sorghum, would define the regional economics of energy crop production.

The analysis is also based on the assumption that differences in soil quality, climate, and land use across the region will create geographic variation in the cost and potential supplies of energy crop feedstocks. Yields of both conventional crops and energy crops are sensitive to land quality and climate. Consequently, farm-gate prices of biomass should show geographic variability reflective of that sensitivity. Energy crop supplies will be a function not only of yields but also of the availability of agricultural land. The geographic distribution of agricultural land should also be very important in defining regional supply patterns (Fig. 1). Thus, the model structure is designed to capture the effect of these three spatial factors on energy crop price and supply.

Two elements not incorporated in the model structure were transportation costs from field to conversion plant and agricultural risk to farmers. Transportation costs are conversion plant specific, and other analyses for this region have shown over-the-road transportation costs for wood to range from $\$ 10$ to $\$ 20$ per (dry) ton, depending on transport distance (Noon 1993). Transportation costs for switchgrass have not been projected for this region but are assumed to range from $\$ 5$ to $\$ 20$ per ton (Cundiff, J. S., Virginia Polytechnic Institute, Blacksburg, unpublished data, 1993).

The impact of agricultural risk on farmer's decision-making processes is difficult to quantify. Its effects would depend on the supply/demand infrastructure which is unknown at this point. If risk is lower than it is for conventional crops, the farm-gate price could be lower than projected using the concept of a break-even price. If risk is perceived as the same or higher, the farm-gate price might be higher.

The approach used to project potential biomass supplies in the TVA region is diagrammed in Fig. 2 and described in the following five sections of text. The approach is divided into five interconnected stages. In Stages 1-3, geographic-specific values for the components of Eq. (1) are derived and the TVA region land base is characterized. In Stage 4, the farm-gate prices for switchgrass and SRWC wood are calculated. In Stage 5, the projected farm-gate prices and energy crop yields are linked with data on land use and land quality in the region. The potential supply of grass or wood feedstock from energy crop production is projected at the county level, and regionwide supply curves of energy crop feedstock are derived. 


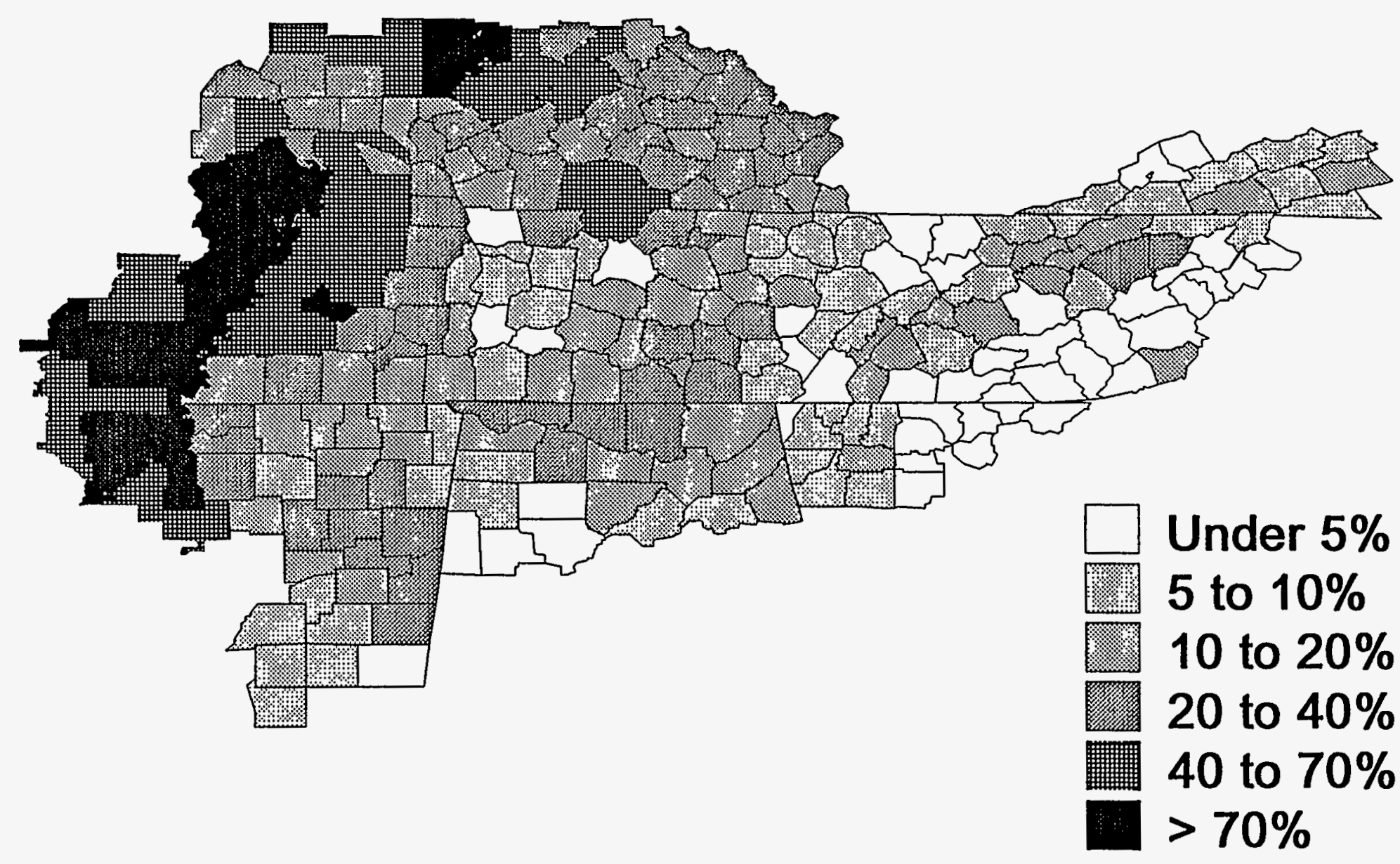

Fig. 1. Percentage of the county land base in crops or pasture. 


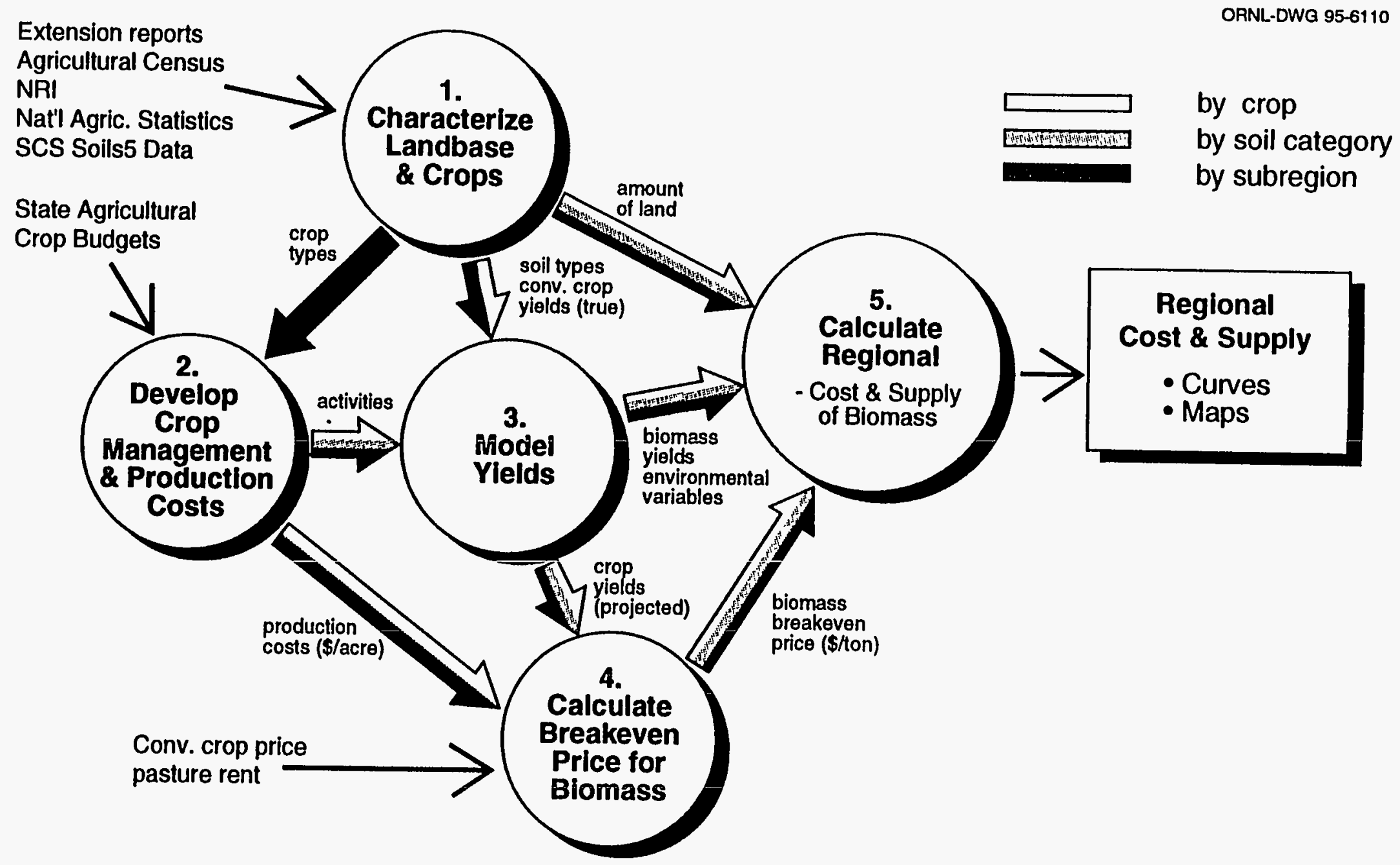

Fig. 2. Five-stage approach used to develop maps of potential biomass supplies in the TVA region and to create regional biomass
supply curves. 


\section{CHARACTERIZE LAND BASE AND CROPS-STAGE 1}

In this stage, land use, soils, current crops, and crop yields in the 276-county region are characterized. To capture intraregional physiographic and climatic differences that influence energy crop and conventional crop yields, the region is broken into eight subregions (Fig. 3). Boundaries of subregions are based on current land use and physiographic features and largely followed the U.S. Department of Agriculture's (USDA's) Major Land Resource Areas (MLRA) (USDA 1981). The three most dominant conventional crops (in terms of acreage planted) in each of the eight subregions are identified by using national agricultural statistics for 1988-1989 (USDA 1989). In the Northwest, Nashville, Plateau and Delta/Coastal Plain subregions, the crops are corn, soybeans, and wheat. In the Ridge and Valley and North Alabama subregions, the crops are corn, cotton, and soybeans, and in the Smokies and Western Uplands subregions, they are cotton, soybeans, and wheat. National Agricultural Statistical Service data at the county level for 1988, 1989, and 1990 are also used to calculate the average yield of the three dominant crops within each subregion (USDA 1989).

Soil Conservation Service (SCS) agricultural capability classes are used to characterize soil quality. The classes signify limitations in crop choice and are based on soil and site characteristics. There are eight general classes ranging from 1 (few limitations restricting cropland use) to 8 (precluded from cropland use). Classes 5-8 are generally unsuitable for growing crops. Within classes $2-8$, four subclasses define the primary cause of cropland limitations. These subclasses are $w$ (excessive water), e (erosion potential), s (soil restrictions-salinity, shallowness, or texture problems), and c (climate restrictions). For the analysis, the $29 \mathrm{SCS}$ classes are aggregated into nine soil categories by grouping classes $5-8$ into one category and grouping classes $3 w$ and $4 w$ together and classes $3 s$ and $4 s$ together. This grouping results in nine categories-1, 2e, $2 s, 2 w, 3 e, 3-4 s$, $3-4 w, 4 e$, and 5+. No climate-restricted soils are present in the study area, and $2 s$ and $3-4 \mathrm{~s}$ soils are rare or absent.

The 1982 National Resources Inventory (NRI) data base (SCS 1984) is used to determine (1) the relative distribution of cropland and pastureland across the nine soil categories in each subregion, (2) the relative proportion of the cropland planted to each of the three most dominant crops in each soil category in each subregion, and (3) the SCS soil name most commonly (in terms of acreage) associated with a particular soil category in each subregion. The most common soil name for each soil category in each subregion is further characterized by means of the SCS SOILS5 database.

Land-use data from the 1987 Agricultural Census (U.S. Department of Commerce 1989) are used to quantify the amount of cropland and pastureland in each county. In the analysis, "cropland" includes all cropland categories in the census, except for cropland used for grazing and pasture or planted to tobacco, horticulture, orchards, or vegetables. The 


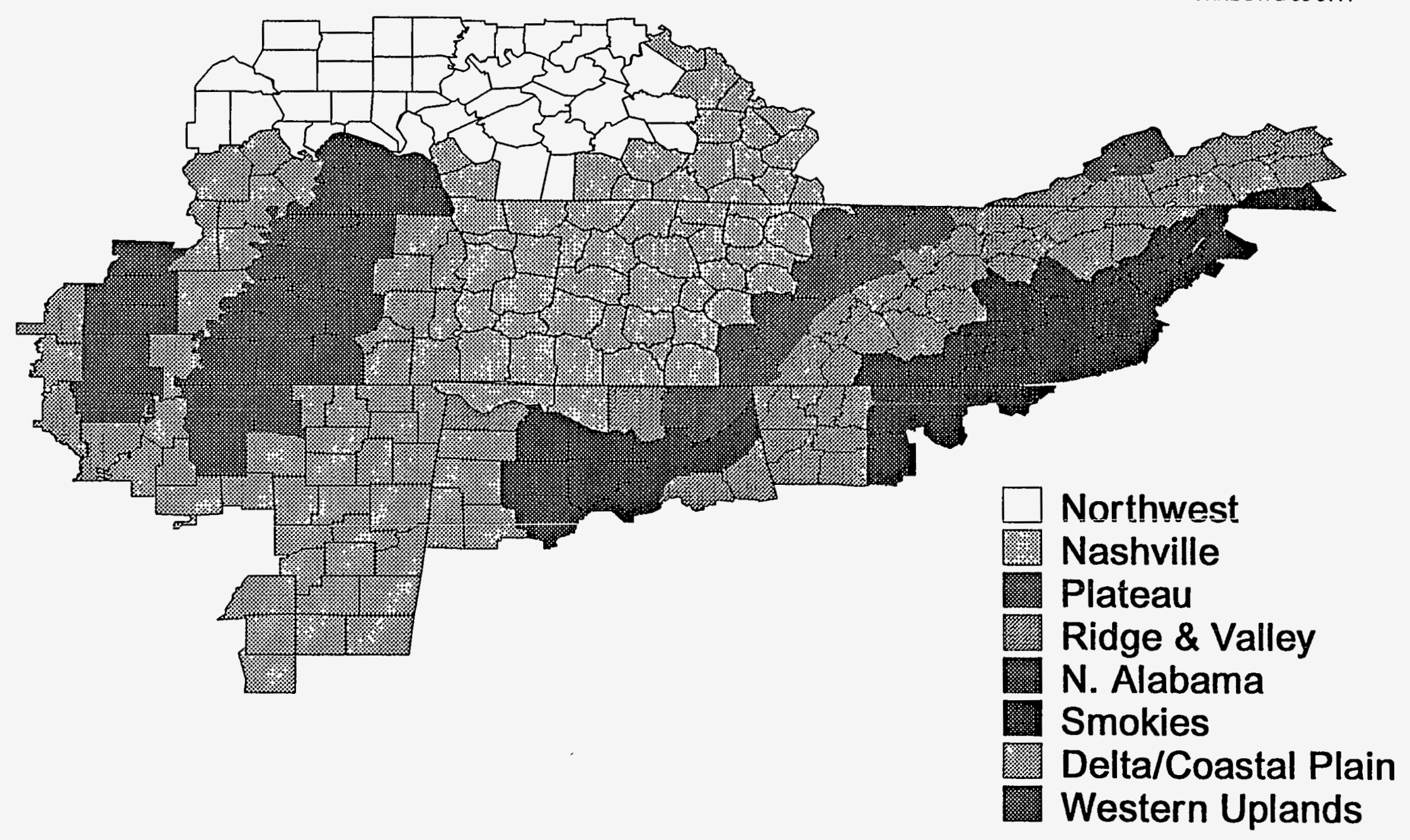

Fig. 3. Subregions in the TVA region. 
latter cropland is excluded because it is highly profitable and unlikely to be converted to energy crops. Pasture is defined as the sum of two census categories-permanent pasture and cropland used for grazing and pasture. The resulting county-level acreage for cropland and pasture is then apportioned among the nine soil categories according to the soil category/land use relationships derived from the NRI for the county's subregion.

\section{DEVELOP CROP MANAGEMENT AND PRODUCTION COSTS-STAGE 2}

For conventional crops-soybeans, cotton, corn, and wheat, The University of Tennessee (UT) Agricultural Extension Service publication Guide to Farm Planning manual (Johnson 1990) is used as the basis for defining crop management activities and crop production costs. These include application and timing of fertilizer, harvest date, labor costs, and equipment usage.

In lieu of determining the value of production from pastureland and the costs of maintaining pasture [left side of Eq. (1)], the USDA Economic Research Service's dollarper-acre value of pastureland rent is used (USDA 1990). These values are specific to each state. The pasture rent value for the state that dominates a subregion defines the pasture rent value for that subregion. Thus for pastureland, the left side of the breakeven equation is a constant, sensitive only to subregion.

Several tree species are suitable for SRWC production within the TVA region: sweetgum (Liquidambar styraciflua), poplar (Populus spp.), sycamore (Platanus occidentalis), and black locust (Robinia pseudoacacia). In this analysis, each species is assigned to the soil categories for which it is projected to have the best growth relative to the other species. Poplar is assigned to the 1 and $2 \mathrm{w}$ soil categories, sweetgum to the $2 \mathrm{e}$ and $2 s$ soil categories, black locust to the $3 e$ and $3-4 s$ categories, and sycamore to the $3-4 w$ category. No SRWC species is considered suitable for growing on soil categories $4 \mathrm{e}$ and $5+$.

Previous information collected by field researchers from experimental field production of SRWC was used to outline management scenarios and construct production costs for each of the species. Rotations varied in length from 6 to 10 years, and coppice rotations were assumed for poplar, sweetgum, and sycamore. Although species are managed differently, all species are assumed to have uniform harvest loss of $15 \%$ of the standing yield. The management schemes for pasture conversion are the same as for plantation establishment on cropland but include more site preparation. The SRWC management schemes do not vary between the two SRWC production scenarios (current yields and $25 \%$ increase in current yields).

Two management schemes were developed for switchgrass-one for establishment on pasture and one for establishment on cropland. Both are based on work by Bransby and Parrish (Bransby et al. 1990; Parrish et al. 1990). In both cases, harvest/storage losses 
of $14 \%$ are assumed and switchgrass is reestablished every 10 years. Unlike SRWC, switchgrass production is considered possible on all nine soil categories, including $4 \mathrm{e}$ and 5+. Thus, the potential land base for switchgrass production is slightly larger. As with SRWC,-management schemes for switchgrass do not vary for the two switchgrass scenarios (current and $25 \%$ increased yields).

Production costs for both SRWC and switchgrass include materials (seedlings or seeds, fertilizer, and pesticides), equipment, and hourly labor costs. SRWC production costs also include contract aerial spraying of pesticides and contract harvesting and chipping. The discount rate is set at $6 \%$. Machine labor rates are assumed to be fixed at $\$ 7.80 / \mathrm{h}$. Harvesting and chipping costs account for nearly half of the total cost of SRWC production and are sensitive to the amount of wood harvested per acre. SRWC harvest and chipping costs are assumed to be $\$ 17$ per (dry) ton if 30 (dry) tons are harvested per acre and to increase if fewer tons are harvested (Anthony Turhollow, Oak Ridge National Laboratory, Oak Ridge, personal communication). Harvesting costs account for about $40 \%$ of the production costs for switchgrass and are sensitive to the amount harvested per acre.

\section{MODEL YIELDS-STAGE 3}

The Erosion Productivity Impact Calculator (EPIC) model developed by the USDA Agricultural Research Service (ARS) is used to predict the yields associated with the four conventional crops and switchgrass (Sharpley and Williams 1990). EPIC is a simulation model of erosion, plant growth, and related soil and water processes. It has a daily time step and is designed to simulate agricultural crop growth and soil responses to management practices on various soils under various climatic conditions. Because erosion impacts on crop productivity can develop slowly, the model is designed to simulate up to hundreds of years of cropping practices.

The EPIC model was initially developed by ARS to assist in the 1985 status report on the nation's soil and water resources as required under the Soil and Water Resource Conservation Act. Because the purpose of the model was to address the wide variation in crop productivity and soil resources that exist in the United States, the model was designed to be as mechanistic as possible. Inputs to the model include soil characteristics, daily weather data (precipitation, maximum temperature, minimum temperature, solar radiation, and wind speed), crop parameters (e.g., maximum leaf area index, maximum root depth, and optimal nitrogen concentration in plant tissue), and management practices (date of planting, date of harvest, date and amount of fertilizer application, tillage practice, etc.). The model considers only one crop at a time, although crop rotations over time are allowed. It also assumes uniform field conditions. The model can accept up to ten different soil horizons. 
The EPIC model has been widely used and adapted for many crops (Sharpley and Williams 1990). One of the convenient features of the model is that it comes with related crop parameter, weather, and soil data bases. Thus the user does not need to develop all of the input parameters.

Crop parameters developed for EPIC by ARS were used to model the four dominant conventional crops. The parameters used for switchgrass were adapted from EPIC hay parameters by Burton English (UT Department of Agricultural Economics, personal communication), working with ARS researchers.

The EPIC model, used to simulate 30 years of continuous crop production, uses weather data uniquely characteristic of each subregion, soils specific to each subregion and each of the nine soil categories, and management practices specific to each crop. A total of 288 EPIC runs were simulated. Average values (over 30 years) were calculated for annual crop yield (dry tons, bushels, or bales per acre per year). For each of the conventional crops in each subregion, the yields predicted by EPIC were adjusted by the actual average yield in the subregion (as characterized in Stage 1) by applying the following formula:

$$
Y_{i}=E_{i} \quad\left(\frac{Y_{\mathrm{dg}}}{\sum E_{i} P_{i}}\right)
$$

where

$Y_{i} \quad=$ adjusted crop yield for soil category $i$,

$E_{i} \quad=$ EPIC predicted yield for soil category $i$,

$P_{i} \quad=$ proportion of crop in the subregion planted on lands of soil category $i$,

$Y_{\mathrm{avg}}=$ average yield of crop within the subregion.

In this manner, the sensitivity of conventional-crop yields to soil quality was predicted.

The soil- and subregion-specific switchgrass yields projected by EPIC were used without modification as estimates of switchgrass yield on former cropland. Estimates of switchgrass yield on former pastureland were developed by decreasing the projected cropland switchgrass yields by $10 \%$.

Because EPIC does not yet include a simulation module for any of the SRWC species and little SRWC field data are available specific to the 276-county region, expert opinion was used to derive expected yields for SRWC plantations. 


\section{CALCULATE BREAK-EVEN PRICE FOR BIOMASS-STAGE 4}

\subsection{Pastureland}

For each soil category in each subregion, pasture rent values and energy crop production costs determined in Stage 2 and the energy crop yields determined in Stage 3 were used to calculate the break-even price for energy-crop biomass produced on pastureland. This break-even price was then used as the farm-gate price for biomass grown on pastureland of that soil category.

\subsection{Cropland}

Crop yields and production costs generated in Stages 2 and 3 were used to develop break-even prices for biomass for each soil category in each subregion. Equation (1) and the market price of conventional crops were used to calculate the prices. The market price was calculated as the average of the years 1989, 1990, and 1991 and does not vary across the region or with soil category $($ corn $=\$ 2.55 / \mathrm{bu}$, wheat $=\$ 3.38 / \mathrm{bu}$, soybeans $=$ $\$ 6.53 / \mathrm{bu}$, and cotton $=\$ 274.50$ per bale). The break-even price associated with the most profitable of the three crops (i.e., the highest break-even price) was used as the farm-gate price for harvested energy crop biomass. If conventional crop yields were such that Eq. (1) predicted a negative land rent, a land rent value of zero was used to calculate the farm-gate price. This ensures that the farm-gate price is sufficient to cover the production costs of the energy biomass.

\subsection{CALCULATE REGIONAL COST AND SUPPLY OF BIOMASS-STAGE 5}

The farm-gate prices for harvested energy-crop biomass calculated in Stage 4 were merged with information from Stage 1 on the acreage of land in each county (by land use and soil category) and information from Stage 3 on energy crop yields to determine the county-specific potential supplies of biomass at the farm-gate price specific to each soil/land use category. This price and supply information was then linked with locations, species, and acreage information to produce county-level maps of potential energy-crop biomass supplies at various farm-gate prices and for various regional biomass supply curves. 


\section{RESULTS AND DISCUSSION}

\subsection{YIELDS, PRODUCTION COSTS, AND FARM-GATE PRICES}

Information on the yields, production costs, and farm-gate prices for both SRWC and switchgrass are presented in this section. They are discussed in the context of subregions and soil categories and from an agricultural rather than an energy perspective.

Some discussion of land rents is useful to this section because they strongly influence the projected farm-gate prices for both SRWC wood and switchgrass. Land rents, as calculated on the basis of conventional crop production and market prices, range from $\$ 0$ to $\$ 182$ per acre per year, with most land rents below $\$ 100$ per acre (Table 1$)$. With few exceptions, land rents are highest on the best cropland (category 1 ) or on wetter soils (category 2w). The North Alabama and Delta/Coastal Plain subregions have low land rents on all soil categories, whereas the Northwest subregion has notably higher land rents than the other subregions. Every subregion except the Northwest and Western Uplands subregions has at least one common soil category with a land rent below $\$ 10$ per acre per year. These projected low land rent soils figure prominently in the supply maps presented in this section, and the validity of their valuation is worth discussing.

Evidence exists to support the projected low land rents. First, farmland in the TVA region has recently been shifting to pasture use, suggesting that conventional crops are not profitable on many soils. Second, the lowest land rents occur in subregions that have very little agricultural land, whereas the highest land rents occur in a subregion that has considerable agricultural land. Third, a previous projection of SRWC prices in East Tennessee found that inclusion of commodity payment programs increases the price of SRWC wood by $\$ 5$ to $\$ 10$ per (dry) ton (Graham et al. 1992), suggesting that existing commodity programs typically contribute $\$ 20$ to $\$ 40$ to land rent in East Tennessee. The same study estimates the average agricultural land rent to be around $\$ 60$ per acre per year, with the inclusion of commodity payments (English, B. C., The University of Tennessee, Knoxville, unpublished data, June 1992). To summarize, the projected land rents appear to be realistic reflections of agricultural land values across the region. However, although the overall land rent patterns projected by the analysis are probably reliable, the specific land rent for any one soil category in any one subregion should be viewed with some skepticism.

\subsubsection{SRWC}

SRWC harvested yields are projected to range from 2.4 to 4.3 (dry) tons per acre per year. They vary by land use and soil category, but not by subregion (Table 2). SRWC yields on former pasture are assumed to be $80 \%$ of those on cropland of the same soil 
Table 1. Projected land rents (\$/acre/year) used to calculate farm-gate prices of SRWC and switchgrass

\begin{tabular}{|c|c|c|c|c|c|c|c|c|}
\hline \multirow[b]{2}{*}{$\begin{array}{c}\text { Soil } \\
\text { category }\end{array}$} & \multicolumn{8}{|c|}{ Subregion } \\
\hline & Northwest & Nashville & Plateau & $\begin{array}{c}\text { Ridge and } \\
\text { Valley }\end{array}$ & N. Alabama & Smokies & $\begin{array}{l}\text { Delta/Coastal } \\
\text { Plain } \\
\end{array}$ & $\begin{array}{l}\text { Western } \\
\text { Uplands } \\
\end{array}$ \\
\hline \multicolumn{9}{|c|}{ Cropland } \\
\hline 1 & 144.37 & 153.94 & 182.75 & 36.89 & 36.51 & 137.74 & 0.00 & 115.56 \\
\hline $2 e$ & 58.68 & 0.00 & 51.58 & 13.70 & 0.00 & 37.50 & 0.00 & 33.93 \\
\hline $2 s$ & 67.12 & 27.40 & 0.00 & 15.64 & 0.00 & 89.76 & 0.00 & 5.20 \\
\hline $2 w$ & 79.08 & 157.28 & 112.12 & 96.64 & 0.00 & 97.52 & 37.60 & 79.20 \\
\hline $3 e$ & 137.74 & 62.97 & 8.58 & 10.88 & 51.52 & 34.90 & 0.00 & 19.58 \\
\hline $3-4 s$ & 37.73 & 57.45 & 0.00 & 18.27 & 47.62 & 0.00 & 0.00 & 41.12 \\
\hline $3-4 w$ & 71.20 & 31.86 & 93.26 & 5.88 & 34.71 & 93.02 & 11.42 & 42.02 \\
\hline $4 e$ & 0.00 & 67.37 & 5.02 & 0.00 & 0.00 & 32.31 & 0.00 & 19.57 \\
\hline $5+$ & 6.40 & 71.10 & 0.00 & 0.00 & 0.00 & 84.02 & 0.00 & 79.18 \\
\hline \multicolumn{9}{|c|}{ Pastureland } \\
\hline 1 & 24.89 & 26.89 & 26.89 & 26.89 & 20.60 & 19.99 & 14.69 & 26.89 \\
\hline $2 e$ & 24.89 & 26.90 & 26.90 & 26.90 & 20.59 & 19.99 & 14.69 & 26.90 \\
\hline $2 s$ & 24.89 & 26.90 & 26.90 & 26.90 & 20.59 & 19.99 & 14.69 & 26.90 \\
\hline $2 w$ & 24.90 & 26.91 & 26.91 & 26.91 & 20.61 & 20.00 & 14.69 & 26.91 \\
\hline $3 e$ & 24.89 & 26.89 & 26.89 & 26.89 & 20.61 & 19.99 & 14.71 & 26.89 \\
\hline $3-4 s$ & 24.89 & 26.89 & 26.89 & 26.89 & 20.61 & 19.99 & 14.71 & 26.89 \\
\hline $3-4 w$ & 24.89 & 26.90 & 26.90 & 26.90 & 20.59 & 19.99 & 14.69 & 26.90 \\
\hline $4 e$ & 24.92 & 26.88 & 26.92 & 26.89 & 20.60 & 20.13 & 14.69 & 26.91 \\
\hline $5+$ & 24.88 & 26.92 & 26.89 & 26.89 & 20.59 & 20.00 & 14.71 & 26.90 \\
\hline
\end{tabular}


Table 2 SRWC production costs and current annual yield by land use and soil category

\begin{tabular}{|c|c|c|}
\hline Soil category & Production (\$/dry ton) ${ }^{a}$ & Yield (dry tons/acre/yr) ${ }^{b}$ \\
\hline \multicolumn{3}{|c|}{ Cropland } \\
\hline 1 & 33.06 & 4.25 \\
\hline $2 e$ & 28.77 & 3.40 \\
\hline $2 s$ & 28.77 & 3.40 \\
\hline $2 w$ & 34.61 & 4.00 \\
\hline $3 e$ & 45.50 & 2.98 \\
\hline $3-4 s$ & 45.50 & 2.98 \\
\hline $3-4 w$ & 41.54 & 3.40 \\
\hline \multicolumn{3}{|l|}{$4 e$} \\
\hline \multicolumn{3}{|l|}{$5+$} \\
\hline \multicolumn{3}{|c|}{ Pastureland } \\
\hline 1 & 43.80 & 3.40 \\
\hline $2 e$ & 43.57 & 2.72 \\
\hline $2 s$ & 43.57 & 2.72 \\
\hline $2 w$ & 46.04 & 3.20 \\
\hline $3 e$ & 62.96 & 2.38 \\
\hline $3-4 s$ & 62.96 & 2.38 \\
\hline $3-4 w$ & 55.57 & 2.72 \\
\hline \multicolumn{3}{|l|}{$4 e$} \\
\hline $5+$ & & \\
\hline
\end{tabular}

aProduction costs include all costs except land rent.

The yield is the harvested yield, not the standing yield. 
category and reflect yield losses due to the compaction and lower fertilizer levels associated with pastureland. The lack of variability across subregions reflects the paucity of SRWC field experience in this region; experts are reluctant to differentiate yields by both subregions and soil categories. SRWC experience in better-defined regions of the United States, such as the midwest, suggests that soil quality has significantly greater effects on SRWC yields than do subtle shifts in climate. Although specific SRWC yields used in the analysis do not vary by subregion, the average SRWC yield of a subregion does vary because the relative dominance of soil categories and land uses varies between subregions. Some subregions have more high-yielding land than others.

Per-acre yield and per-ton production costs vary by land use and soil category because SRWC management practices are soil and land-use specific (Table 2). On former cropland, SRWC production costs range from $\$ 29$ to $\$ 46$ per (dry) ton. Production costs on pastureland range from $\$ 44$ to $\$ 63$ per (dry) ton. The production costs on pastureland are higher than on cropland because of the additional site preparation associated with converting pasture to SRWC plantation and because lower SRWC yields are expected on former pastureland. Sweetgum production costs (soil categories $2 e$ and $2 s$ ) are lower than those of other species because three rotations are assumed, whereas two are assumed for poplar and sycamore and one for black locust. Thus, establishment costs are distributed over considerably more tons of harvested wood for sweetgum than for the other species.

The profitability of conventional crop options, and thus the projected land rent, varies by subregion. Thus, farm-gate prices for SRWC wood do vary by subregion in addition to soil category and land use (Table 3). The lowest-cost SRWC biomass [\$29 per (dry) ton] is associated with soil category $2 \mathrm{e}$ in the Nashville, North Alabama, and Delta/Coastal Plain subregions and soil category $2 s$ in the Western Uplands subregion. The North Alabama and Delta/Coastal subregions have the lowest overall farm-gate prices for SRWC biomass, and the Northwest subregion has the highest. Increasing SRWC yields by $25 \%$ decreases farm-gate prices by $20 \%$.

\subsubsection{Switchgrass}

Because projected switchgrass yields are derived by means of the EPIC crop simulation model, which includes weather variables specific to each subregion, they vary by subregion as well as soil category and land use (Table 4). Projected switchgrass yields are highest on soil categories 1 and $2 \mathrm{w}$ across all subregions, ranging from 5.8 to 8.8 tons per acre per year. The majority of the yields on other soil categories range from 5.5 to 6.0 (dry) tons per acre per year. However, yields as low as 4.3 (dry) tons per acre per year are projected for a few soil categories. The subregions do not display identical patterns of high and low yields. Half of the subregions have one or two soil categories that have significantly higher yields than their other soil categories, and half of the subregions have 
Table 3. Projected SRWC farm-gate prices $[\$ /(d r y)$ ton] by subregion and soil category

\begin{tabular}{|c|c|c|c|c|c|c|c|c|}
\hline \multirow[b]{2}{*}{$\begin{array}{c}\text { Soil } \\
\text { category }\end{array}$} & \multicolumn{8}{|c|}{ Subregion } \\
\hline & Northwest & Nashville & Plateau & $\begin{array}{c}\text { Ridge and } \\
\text { Valley }\end{array}$ & N. Alabama & Smokies & $\begin{array}{c}\text { Delta/Coastal } \\
\text { Plain } \\
\end{array}$ & $\begin{array}{l}\text { Western } \\
\text { Uplands }\end{array}$ \\
\hline \multicolumn{9}{|c|}{ Cropland } \\
\hline 1 & 67.03 & 69.28 & 76.06 & 41.74 & 41.65 & 65.47 & 33.06 & 60.26 \\
\hline $2 e$ & 46.03 & 28.77 & 43.94 & 32.80 & 28.77 & 39.80 & 28.77 & 38.75 \\
\hline $2 s$ & 48.51 & 36.83 & 28.77 & 33.38 & 28.77 & 55.17 & 28.77 & 30.30 \\
\hline $2 w$ & 54.39 & 73.93 & 62.64 & 58.77 & 34,61 & 58.99 & 44.01 & 54.41 \\
\hline $3 e$ & 91.72 & 66.63 & 48.38 & 49.15 & 62.79 & 57.21 & 45.50 & 52.07 \\
\hline $3-4 s$ & 58.16 & 64.78 & 45.50 & 51.63 & 61.48 & 45.50 & 45.50 & 59.30 \\
\hline $3-4 w$ & 62.48 & 50.91 & 68.97 & 43.27 & 51.75 & 68.90 & 44.90 & 53.90 \\
\hline \multicolumn{9}{|l|}{$4 e$} \\
\hline \multicolumn{9}{|l|}{$5+$} \\
\hline \multicolumn{9}{|c|}{ Pastureland } \\
\hline 1 & 51.12 & 51.71 & 51.71 & 51.71 & 49.86 & 49.68 & 48.12 & 51.71 \\
\hline $2 e$ & 52.72 & 53.46 & 53.46 & 53.46 & 51.14 & 50.92 & 48.97 & 53.46 \\
\hline $2 s$ & 52.72 & 53.46 & 53.46 & 53.46 & 51.14 & 50.92 & 48.97 & 53.46 \\
\hline $2 w$ & 53.82 & 54.45 & 54.45 & 54.45 & 52.48 & 52.29 & 50.63 & 54.45 \\
\hline $3 e$ & 73.42 & 74.26 & 74.26 & 74.26 & 71.62 & 71.36 & 69.14 & 74.26 \\
\hline $3-4 s$ & 73.42 & 74.26 & 74.26 & 74.26 & 71.62 & 71.36 & 69.14 & 74.26 \\
\hline $3-4 w$ & 64.72 & 65.46 & 65.46 & 65.46 & 63.14 & 62.92 & 60.97 & 65.46 \\
\hline \multicolumn{9}{|l|}{$4 \mathrm{e}$} \\
\hline $5+$ & & & & & & & & \\
\hline
\end{tabular}


Table 4. Projected switchgrass yield (harvested dry tons/acre/year) by subregion and soil category

\begin{tabular}{|c|c|c|c|c|c|c|c|c|}
\hline \multirow[b]{2}{*}{$\begin{array}{c}\text { Soil } \\
\text { category }\end{array}$} & \multicolumn{8}{|c|}{ Subregion } \\
\hline & Northwest & Nashville & Plateau & $\begin{array}{c}\text { Ridge and } \\
\text { Valley }\end{array}$ & N. Alabama & Smokies & $\begin{array}{c}\text { Delta/Coastal } \\
\text { Plain } \\
\end{array}$ & $\begin{array}{l}\text { Western } \\
\text { Uplands }\end{array}$ \\
\hline \multicolumn{9}{|c|}{ Cropland } \\
\hline 1 & 6.70 & 8.08 & 8.77 & 6.47 & 6.59 & 8.39 & 5.82 & 5.78 \\
\hline $2 e$ & 6.05 & 4.40 & 5.86 & 5.56 & 5.70 & 6.09 & 6.32 & 5.59 \\
\hline $2 s$ & 5.70 & 5.82 & 5.62 & 5.78 & 5.59 & 5.82 & 5.90 & 5.90 \\
\hline $2 w$ & 6.62 & 7.89 & 6.05 & 6.01 & 5.74 & 7.31 & 6.51 & 8.54 \\
\hline $3 e$ & 5.86 & 5.56 & 4.33 & 5.56 & 5.28 & 6.09 & 5.98 & 5.82 \\
\hline $3-4 s$ & 5.78 & 4.40 & 5.56 & 5.51 & 6.01 & 6.62 & 5.90 & 5.78 \\
\hline $3-4 w$ & 4.33 & 5.32 & 5.59 & 5.36 & 6.40 & 5.90 & 5.36 & 5.98 \\
\hline $4 e$ & 6.05 & 5.70 & 4.33 & 5.06 & 4.64 & 6.05 & 5.98 & 5.59 \\
\hline $5+$ & 5.93 & 5.90 & 4.40 & 4.40 & 4.40 & 6.28 & 6.12 & 5.98 \\
\hline \multicolumn{9}{|c|}{ Pastureland } \\
\hline 1 & 6.03 & 7.28 & 7.89 & 5.82 & 5.93 & 7.55 & 5.24 & 5.20 \\
\hline $2 e$ & 5.44 & 3.96 & 5.27 & 5.00 & 5.13 & 5.48 & 5.69 & 5.03 \\
\hline $2 s$ & 5.13 & 5.24 & 5.06 & 5.20 & 5.03 & 5.24 & 5.31 & 5.31 \\
\hline $2 w$ & 5.96 & 7.10 & 5.44 & 5.41 & 5.17 & 6.58 & 5.86 & 7.69 \\
\hline $3 e$ & 5.27 & 5.00 & 3.89 & 5.00 & 4.75 & 5.48 & 5.38 & 5.24 \\
\hline $3-4 s$ & 5.20 & 3.96 & 5.00 & 4.96 & 5.41 & 5.96 & 5.31 & 5.20 \\
\hline $3-4 w$ & 3.89 & 4.79 & 5.03 & 4.82 & 5.76 & 5.31 & 4.82 & 5.38 \\
\hline $4 e$ & 5.44 & 5.13 & 3.89 & 4.55 & 4.17 & 5.44 & 5.38 & 5.03 \\
\hline $5+$ & 5.34 & 5.31 & 3.96 & 3.96 & 3.96 & 5.65 & 5.51 & 5.38 \\
\hline
\end{tabular}


one or two soil categories that produce significantly lower yields than their other soil categories. Specifically, the Nashville, Plateau, Smokies, and Western Uplands subregions have higher yields on categories 1 or $2 w$, whereas the Northwest, Nashville, Plateau, Ridge and Valley, and North Alabama subregions have relatively low yields on category $4 \mathrm{e}$ and/or category $5+$.

Although the per-acre production costs of switchgrass vary only by land use ( $\$ 188$ per acre per year for cropland and $\$ 250$ per acre for pastureland), per-ton costs vary by soil category and subregion because of variations in yield (Table 5). Switchgrass production costs range from $\$ 28$ per (dry) ton to $\$ 64$ per (dry) ton and are higher for pastureland than for cropland of the same soil category.

As with SRWC, switchgrass farm-gate prices vary by soil category, land use, and subregion (Table 6). Except for soil category 1 in the Northwest, Nashville, Smokies, and Plateau subregions, pasture farm-gate prices are higher than cropland farm-gate prices for the same soil categories. This is because the higher per-ton production costs on pastureland are not sufficiently outweighed by lower land rents. Cropland farm-gate prices are lowest in the Delta/Coastal Plain [ $\$ 29$ to $\$ 37$ per (dry) ton] and Ridge and Valley subregions [ $\$ 34$ to $\$ 47$ per (dry) ton] because the projected land rents are low and switchgrass yields are moderate. The farm-gate prices for cropland in the North Alabama subregion are also low [ $\$ 32$ to $\$ 45$ per (dry) ton] primarily because of high switchgrass yields compared with low land rents. Although the Smokies and Western Uplands subregions have a few soil categories with low farm-gate prices, most of their soil categories have fairly high farm-gate prices [ $\$ 47$ to $\$ 52$ per (dry) ton]. The Northwest, Nashville, and Plateau subregions generally have very high farm-gate prices as well as relatively high switchgrass yields.

As with SRWC, increasing switchgrass yields by $25 \%$ decreases farm-gate prices by nearly 20\%. Consequently, the least-cost switchgrass supplies cost $\$ 21$ to $\$ 24$ per (dry) ton vs $\$ 26$ to $\$ 29$ per (dry) ton if yields are increased by $25 \%$.

\subsection{REGIONAL SUPPLY PATTERNS}

In considering the potential for biomass energy in the TVA region from a power production standpoint, it is useful to characterize the potential supply of biomass in terms of its energy content rather than its mass. Characterizing price and supply in terms of energy content facilitates comparisons among qualitatively different supplies such as coal, wood, and grass. For this analysis, it is assumed that SRWC wood has an energy content of $17 \mathrm{MBtu}$ per (dry) ton (Wright et al. 1992b) and that switchgrass has an energy content of $13 \mathrm{MBtu}$ per (dry) ton [Office of Technology Assessment (OTA) 1980]. Figures 4 and 5 show the projected potential county supplies of SRWC wood or switchgrass from agricultural land at three farm-gate prices $-<2.00 / \mathrm{MBtu},<\$ 2.50 / \mathrm{MBtu}$, and $<\$ 3.00 / \mathrm{MBtu}$. 
Table 5. Projected switchgrass production costs [\$/(dry) ton] by subregion and soil category. Production costs include all costs of producing switchgrass except land rent and are based on harvested yield

\begin{tabular}{|c|c|c|c|c|c|c|c|c|}
\hline \multirow[b]{2}{*}{$\begin{array}{c}\text { Soil } \\
\text { category }\end{array}$} & \multicolumn{8}{|c|}{ Subregion } \\
\hline & Northwest & Nashville & Plateau & $\begin{array}{c}\text { Ridge and } \\
\text { Valley }\end{array}$ & N. Alabama & Smokies & $\begin{array}{c}\text { Delta/Coastal } \\
\text { Plain }\end{array}$ & $\begin{array}{l}\text { Western } \\
\text { Uplands }\end{array}$ \\
\hline \multicolumn{9}{|c|}{ Cropland } \\
\hline 1 & 28.00 & 23.20 & 21.38 & 29.00 & 28.37 & 22.37 & 32.22 & 32.45 \\
\hline $2 e$ & 31.02 & 42.60 & 32.03 & 33.76 & 32.90 & 30.80 & 29.67 & 33.55 \\
\hline $2 s$ & 32.90 & 32.22 & 33.35 & 32.45 & 33.55 & 32.22 & 31.79 & 31.79 \\
\hline $2 w$ & 28.32 & 23.78 & 31.02 & 31.20 & 32.65 & 25.66 & 28.81 & 21.96 \\
\hline $3 e$ & 32.03 & 33.76 & 43.36 & 33.76 & 35.52 & 30.80 & 31.38 & 32.22 \\
\hline $3-4 s$ & 32.45 & 42.60 & 33.76 & 34.02 & 31.20 & 28.32 & 31.79 & 32.45 \\
\hline $3-4 w$ & 43.36 & 35.23 & 33.55 & 35.01 & 29.31 & 31.79 & 35.01 & 31.38 \\
\hline $4 e$ & 31.02 & 32.90 & 43.36 & 37.09 & 40.46 & 31.02 & 31.38 & 33.55 \\
\hline $5+$ & 31.61 & 31.79 & 42.60 & 42.60 & 42.60 & 29.88 & 30.63 & 31.38 \\
\hline \multicolumn{9}{|c|}{ Pastureland } \\
\hline 1 & 41.48 & 34.37 & 31.68 & 42.97 & 42.18 & 33.14 & 47.73 & 48.08 \\
\hline $2 \mathrm{e}$ & 45.96 & 63.11 & 47.45 & 50.02 & 48.73 & 45.64 & 43.96 & 49.71 \\
\hline $2 s$ & 48.73 & 47.73 & 49.40 & 48.08 & 49.71 & 47.73 & 47.10 & 47.10 \\
\hline $2 w$ & 41.96 & 35.24 & 45.96 & 46.22 & 48.37 & 38.01 & 42.68 & 32.54 \\
\hline $3 e$ & 47.45 & 50.02 & 64.24 & 50.02 & 52.62 & 45.64 & 46.49 & 47.73 \\
\hline $3-4 s$ & 48.08 & 63.11 & 50.02 & 50.41 & 46.22 & 41.96 & 47.10 & 48.08 \\
\hline $3-4 w$ & 64.24 & 52.20 & 49.71 & 51.86 & 43.43 & 47.10 & 51.86 & 46.49 \\
\hline $4 e$ & 45.96 & 48.73 & 64.24 & 54.95 & 59.95 & 45.96 & 46.49 & 49.71 \\
\hline $5+$ & 46.83 & 47.10 & 63.11 & 63.11 & 63.11 & 44.26 & 45.38 & 46.49 \\
\hline
\end{tabular}


Table 6. Estimated switchgrass farm-gate prices [\$/(dry) ton] by subregion and soil category

\begin{tabular}{ccccccccc}
\hline \multirow{2}{*}{$\begin{array}{c}\text { Soil } \\
\text { category }\end{array}$} & Northwest & Nashville & Plateau & $\begin{array}{c}\text { Ridge and } \\
\text { Valley }\end{array}$ & N. Alabama & Smokies & $\begin{array}{c}\text { Delta/Coastal } \\
\text { Plain }\end{array}$ & $\begin{array}{c}\text { Western } \\
\text { Uplands }\end{array}$ \\
\cline { 2 - 8 } & & & \multicolumn{7}{c}{ Cropland } \\
1 & 49.55 & 42.25 & 42.22 & 34.70 & 34.01 & 38.79 & 32.22 & 52.44 \\
$2 \mathrm{e}$ & 40.72 & 42.60 & 40.83 & 36.22 & 32.90 & 36.96 & 29.67 & 39.62 \\
$2 \mathrm{~s}$ & 44.67 & 36.93 & 33.35 & 35.16 & 33.55 & 47.64 & 31.79 & 32.67 \\
$2 \mathrm{w}$ & 40.27 & 43.71 & 49.55 & 47.28 & 32.65 & 39.00 & 34.59 & 31.23 \\
$3 \mathrm{e}$ & 55.54 & 45.08 & 45.34 & 35.72 & 45.28 & 36.53 & 31.38 & 35.58 \\
$3-4 \mathrm{~s}$ & 38.98 & 55.66 & 33.76 & 37.34 & 39.12 & 28.32 & 31.79 & 39.57 \\
$3-4 \mathrm{w}$ & 59.80 & 41.22 & 50.23 & 36.10 & 34.73 & 47.56 & 37.14 & 38.41 \\
$4 \mathrm{e}$ & 31.02 & 44.72 & 44.52 & 37.09 & 40.46 & 36.36 & 31.38 & 37.05 \\
$5+$ & 32.69 & 43.84 & 42.60 & 42.60 & 42.60 & 43.26 & 30.63 & 44.62 \\
& & & & Pastureland & & & & \\
1 & 45.61 & 38.07 & 35.09 & 47.59 & 45.65 & 35.79 & 50.54 & 53.25 \\
$2 \mathrm{e}$ & 50.54 & 69.90 & 52.55 & 55.40 & 52.75 & 49.29 & 46.54 & 55.06 \\
$2 \mathrm{~s}$ & 53.58 & 52.86 & 54.72 & 53.25 & 53.81 & 51.55 & 49.87 & 52.17 \\
$2 \mathrm{w}$ & 46.14 & 39.03 & 50.90 & 51.19 & 52.35 & 41.05 & 45.19 & 36.04 \\
$3 \mathrm{e}$ & 52.17 & 55.40 & 71.16 & 55.40 & 56.96 & 49.29 & 49.22 & 52.86 \\
$3-4 \mathrm{~s}$ & 52.87 & 69.90 & 55.40 & 55.83 & 50.03 & 45.32 & 49.87 & 53.25 \\
$3-4 \mathrm{w}$ & 70.64 & 57.82 & 55.06 & 57.44 & 47.01 & 50.87 & 54.91 & 51.49 \\
$4 \mathrm{e}$ & 50.54 & 53.97 & 71.16 & 60.86 & 64.89 & 49.64 & 49.22 & 55.06 \\
$5+$ & 51.49 & 52.17 & 69.90 & 69.90 & 68.31 & 47.80 & 48.05 & 51.49 \\
\hline
\end{tabular}




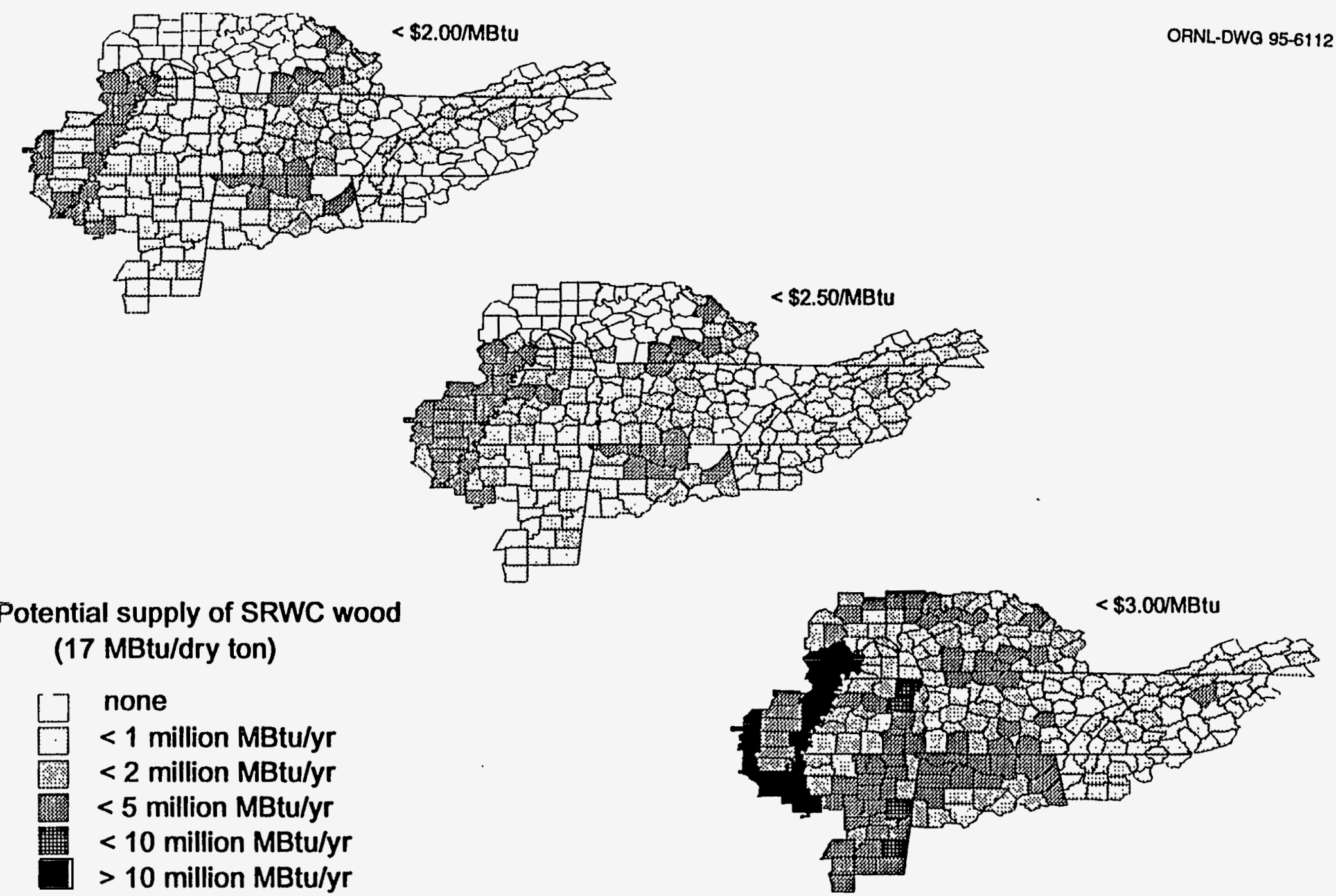

Fig. 4. Amount of SRWC wood feedstock (in MBtu) that could potentially be produced in the TVA region counties at a farmgate price of less than $\$ 2.00 / \mathrm{MBtu}$, less than $\$ 2.50 / \mathrm{MBtu}$, and less than $\$ 3.00 / \mathrm{MBtu}$. The farm-gate price does not include transportation cost. 


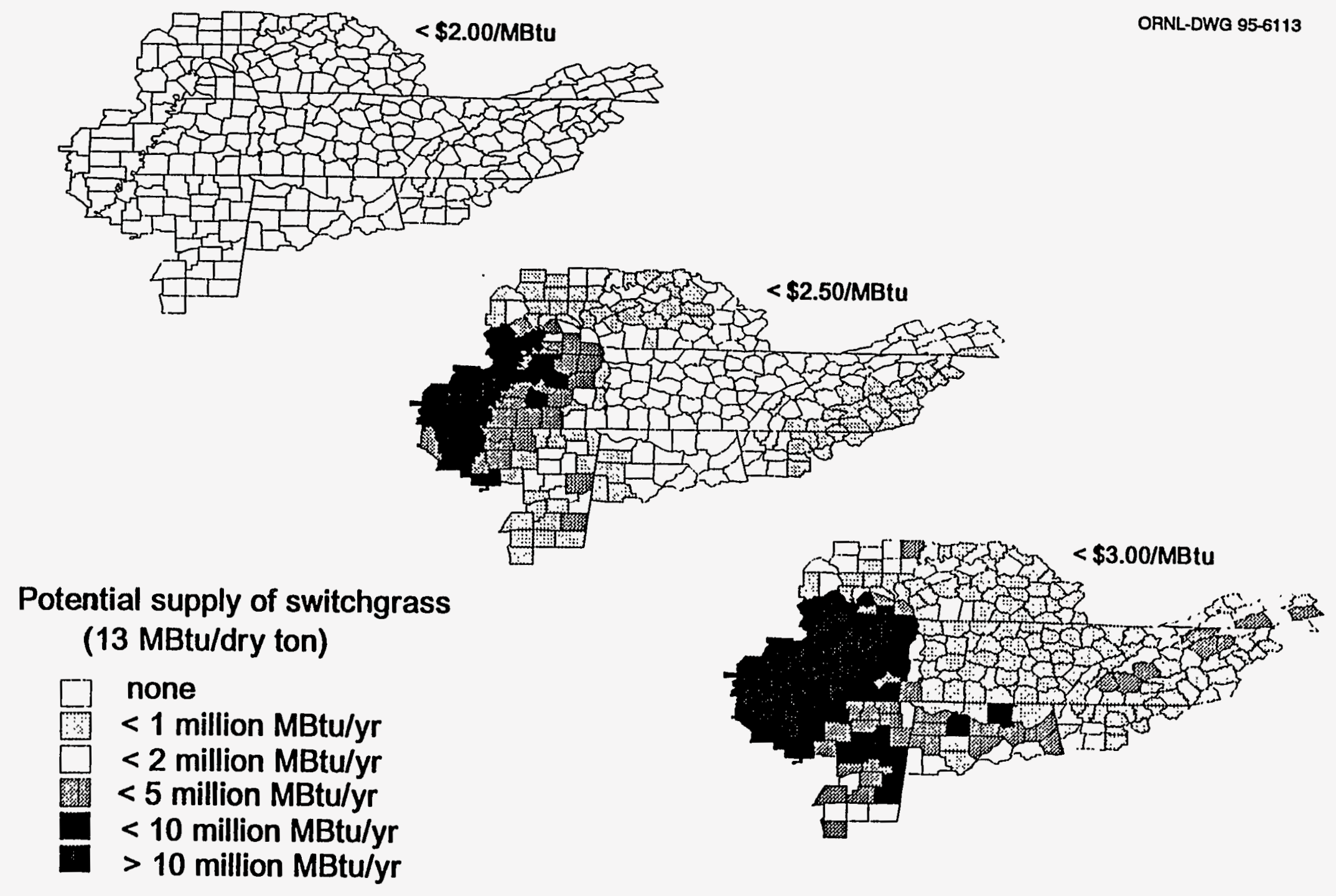

Fig. 5. Amount of switchgrass feedstock (in MBtu) that could potentially be produced in the TVA region counties at a farm-gate price of less than $\$ 2.00 / \mathrm{MBtu}$, less than $\$ 2.50 / \mathrm{MBtu}$, and less than $\$ 3.00 / \mathrm{MBtu}$. The farm-gate price does not include transportation cost. 
It is important to recognize the influence of subregion boundaries (Fig. 3) and county land use (Fig. 1) on these patterns when interpreting the supply-cost patterns evident in these maps. Subregion boundaries strongly influence projected farm-gate prices across the entire region through their influence on determinants of land rent value of different soil categories. The specific conventional crops grown, their production costs, and their expected soil-specific yields are unique to each subregion. The conventional crop yields on specific soil categories are particular to each subregion because subregion-specific information is an input in the crop simulation program (EPIC) used to project these yields. This information includes management activities, soil names representing soil categories, and climate. In the case of switchgrass, subregion boundaries also influence farm-gate prices through their influence on switchgrass yield. However, subregion boundaries do not affect all determinants of farm-gate price. Certain elements, such as SRWC yields on different soil categories, per-acre production costs for either SRWC or switchgrass, and crop market prices, are uniform across the region.

The subregion boundaries also affect the potential amount of feedstock supply but to a lesser extent, especially for wood feedstock. Boundaries affect supply amount not only because they directly affect switchgrass yield but also because they are used to define the proportions of county cropland and pastureland acreage associated with each soil category. These proportions affect biomass supply because different biomass yields are expected on the nine soil categories.

The potential amount of biomass feedstock is most affected by the acreage of cropland and pastureland potentially available for growing biomass. Those values are, however, defined by county rather than subregion (Fig. 1). Thus, although the proportion of cropland or pastureland acreage in a particular soil category is uniform for all counties in that subregion, the actual acreage of that soil category is unique to a county as are the total cropland and pastureland acreages. Therefore, because the farm-gate price is unique to a soil category, the potential feedstock supply at a particular farm-gate price is unique to a county.

\subsubsection{Projected SRWC Supplies at Current Biomass Yield Level}

Assuming current technology and a farm-gate price of less than $\$ 2.00 / \mathrm{MBtu}$ [ $\$ 34$ per harvested (dry) ton @ 17 MBtu per (dry) ton] the potential supplies of SRWC wood are greatest in the North Alabama subregion, far-western portions of the Delta/Coastal Plan subregion, and the eastern portion of the Nashville subregion (Fig. 4). This level of production in these counties is a consequence of subregion soil categories with low farmgate prices and relatively high densities of agricultural land. The Ridge and Valley subregion also has a low-cost soil category; however, this does not influence the regional supply pattern because none of the counties of this subregion have much agricultural land. 
At \$2.50/MBtu (Fig. 4), the Western Uplands subregion is also projected to provide substantial SRWC wood supplies because of the availability of plentiful $2 \mathrm{e}$ soils with a farm-gate price of $\$ 2.28 / \mathrm{MBtu}$. The Smokies subregion also has $2 \mathrm{e}$ land with a farm-gate price under $\$ 2.50 / \mathrm{MBtu}$, but sparseness of agricultural land in that subregion results in small projected potential supply per county.

At $\$ 3.00 / \mathrm{MBtu}$ (Fig. 4), all counties are projected to have some potential for supplying SRWC wood, but the potential supply is greatest in the western and southwestern counties of the region where agriculture is the dominant land use. The farwestern counties in the Delta/Coastal Plain subregion are projected to be able to supply millions of tons of SRWC wood. Although the counties of the Northwest subregion are also dominated by agriculture, many of the subregion's soil categories have projected farmgate prices exceeding \$3.00/MBtu because conventional crops have high yields in that subregion.

\subsubsection{Projected Switchgrass Supplies at Current Biomass Yield Level}

Assuming current technology and a farm-gate price of less than \$2.00/MBtu [\$26 per (dry) ton $^{3}$ ), switchgrass production is not projected for any county (Fig. 5). At $\$ 2.50 / \mathrm{MBtu}$, potential switchgrass production was mainly relegated to those counties in which land with low returns from conventional crops (low land rent) can produce moderate to high yields of switchgrass (Fig. 5). The potential supplies of switchgrass in counties in the Northwest and Smokies subregions are due to a single uncommon soil category (4e in the Northwest subregion and 3-4s in the Smokies subregion) with a low projected land rent and moderate switchgrass yield. Potential supplies are projected to be fairly abundant in the Delta/Coastal Plain subregion because all the cropland soil categories except for the wet-soil categories $2 w$ and $3-4 w$ have farm-gate prices under $\$ 2.50 / \mathrm{MBtu}$, largely because of very low land rents in this subregion. The wet-soil categories have higher land rents and consequently higher farm-gate prices for biomass. The higher supply in the western counties of Delta/Coastal Plain subregion reflects the greater abundance of agricultural land in that portion of the subregion. Unlike the subregions with potential switchgrass supplies caused by low land rents, the Western Uplands subregion has a fairly high supply because one of its common soil categories has a very high switchgrass yield [8.5 (dry) tons per acre], which creates a low farm-gate price, even though the net returns for conventional crops on that soil are moderate to high (about $\$ 80$ per acre). Four subregions (Nashville, Plateau, Ridge and Valley, and North

\footnotetext{
${ }^{3}$ Assumes an energy content of $13 \mathrm{MBtu} / \mathrm{dry}$ ton (OTA 1980), which may be low. A higher energy content would, of course, lower the energy cost.
} 
Alabama) show no supply at a farm-gate price of $\$ 2.50 / \mathrm{MBtu}$ or less because switchgrass yields are low on the soil categories with projected low land rent.

At $\$ 3.00 / \mathrm{MBtu}$ (Fig. 5), all counties in all subregions can potentially supply some switchgrass. Most of the counties in the Delta/Coastal Plain and Western Uplands subregions are capable of supplying large quantities of switchgrass, especially in the far western counties of Missouri, Arkansas, and Tennessee. At this farm-gate price, the Ridge and Valley subregion becomes a much more significant potential source of switchgrass feedstock because of its abundance of land with moderate switchgrass yields, low land rents, and farm-gate prices between $\$ 2.50 / \mathrm{MBtu}$ and $\$ 3.00 / \mathrm{MBtu}$. In contrast, raising the farm-gate price from $\$ 2.50 / \mathrm{MBtu}$ to $\$ 3.00 / \mathrm{MBtu}$ does not increase potential switchgrass supplies in the Smokies subregion because of relatively low amounts of agricultural land in that subregion, much of which is pastureland with high switchgrass production costs. The lack of switchgrass supply in the Nashville subregion is due to very low switchgrass yields projected for most of the soil categories.

\subsection{Projected SRWC and Switchgrass Supplies at a 25\% Higher Yield Level}

A $25 \%$ increase in biomass yields, as might be expected with future production technology, decreases farm-gate price by nearly $20 \% .^{4}$ Consequently, the spatial patterns of SRWC and switchgrass biomass supplies at $\$ 2.00 / \mathrm{MBtu}$ at the $25 \%$ higher yields are very similar to the spatial patterns of biomass at $\$ 2.50 / \mathrm{MBtu}$ at the original yields (Figs. 6 and 7). At $\$ 2.50 / \mathrm{MBtu}$ or $\$ 3.00 / \mathrm{MBtu}$ and a $25 \%$ increase in yields, the spatial patterns in supply observed at the original yields (Figs. 4 and 5) are simply strengthened.

\subsection{PROJECTED REGIONAL SUPPLY CURVES}

Figures 8 and 9 portray the TVA regional supply curves for SRWC and switchgrass grown on agricultural land in the TVA region. Each point on the curves depicts the cost per MBtu to supply different levels of energy (million MBtus) in the form of wood (in the case of SRWC) or grass (in the case of switchgrass). The curves, like the analysis, do not take into account any effect that changing land use (by growing energy crops) might have on land rents across the region. These curves are useful in projecting the total potential supply of energy from biomass crops across the entire region.

Assuming all determinants of supply (e.g., market price, land rent, and production costs) are held constant and that all crop and pasture acreage in the region can be converted to SRWC or switchgrass, the agricultural crop and pastureland in the TVA

\footnotetext{
${ }^{4}$ All other determinants of supply-conventional crop yields, costs of production, and market prices-are assumed to be the same as for the current technology scenario. This is probably not realistic, but the analysis does show the impact of switchgrass yield on supply.
} 


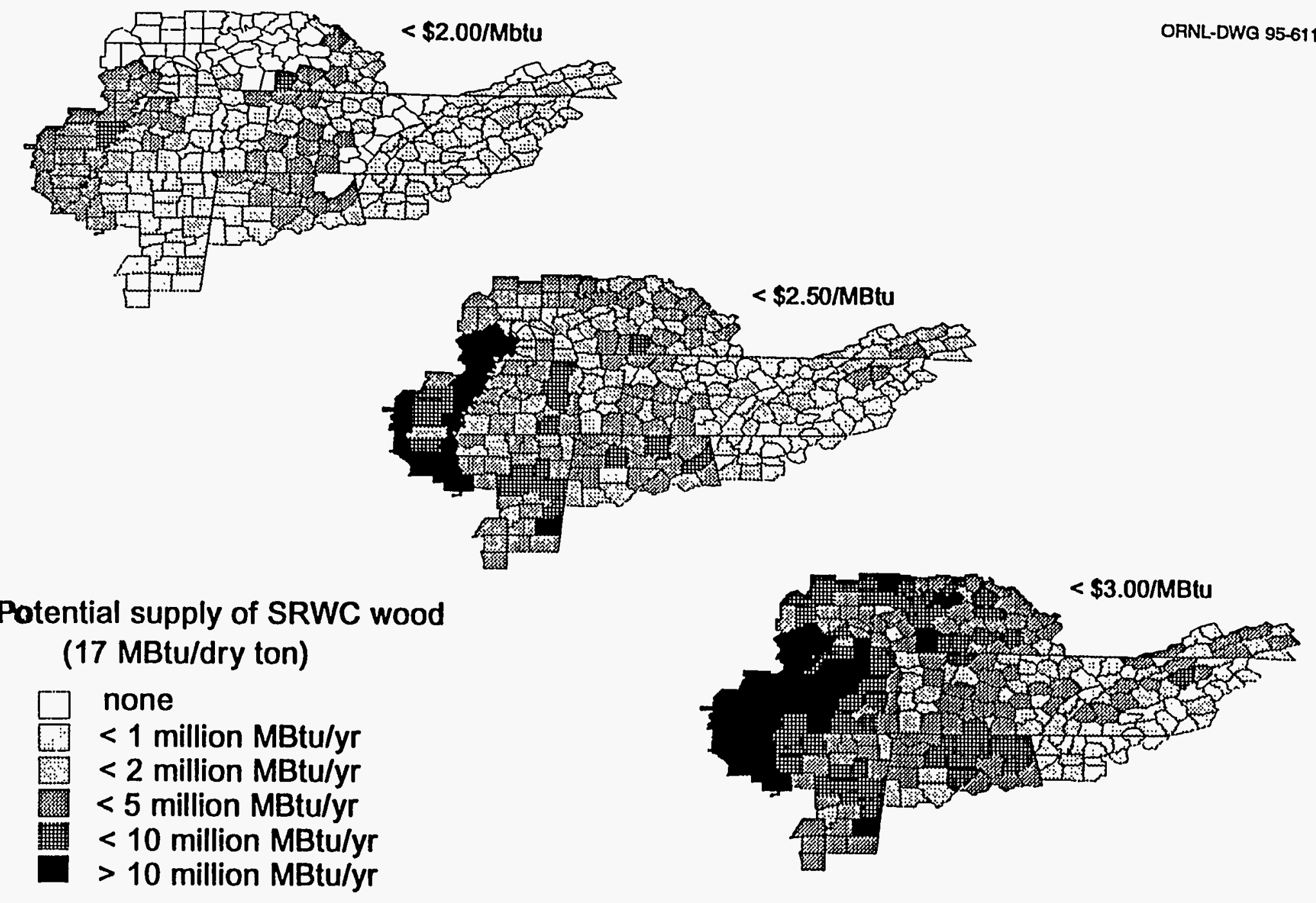

Fig. 6. Amount of SRWC wood feedstock (in MBtu) that could potentially be produced in the TVA region counties at a farmgate price of less than $\$ 2.00 / \mathrm{MBtu}$, less than $\$ 2.50 / \mathrm{MBtu}$, and less than $\$ 3.00 / \mathrm{MBtu}$ if current SRWC yields were increased $25 \%$.
The farm-gate price does not include transportation cost. 


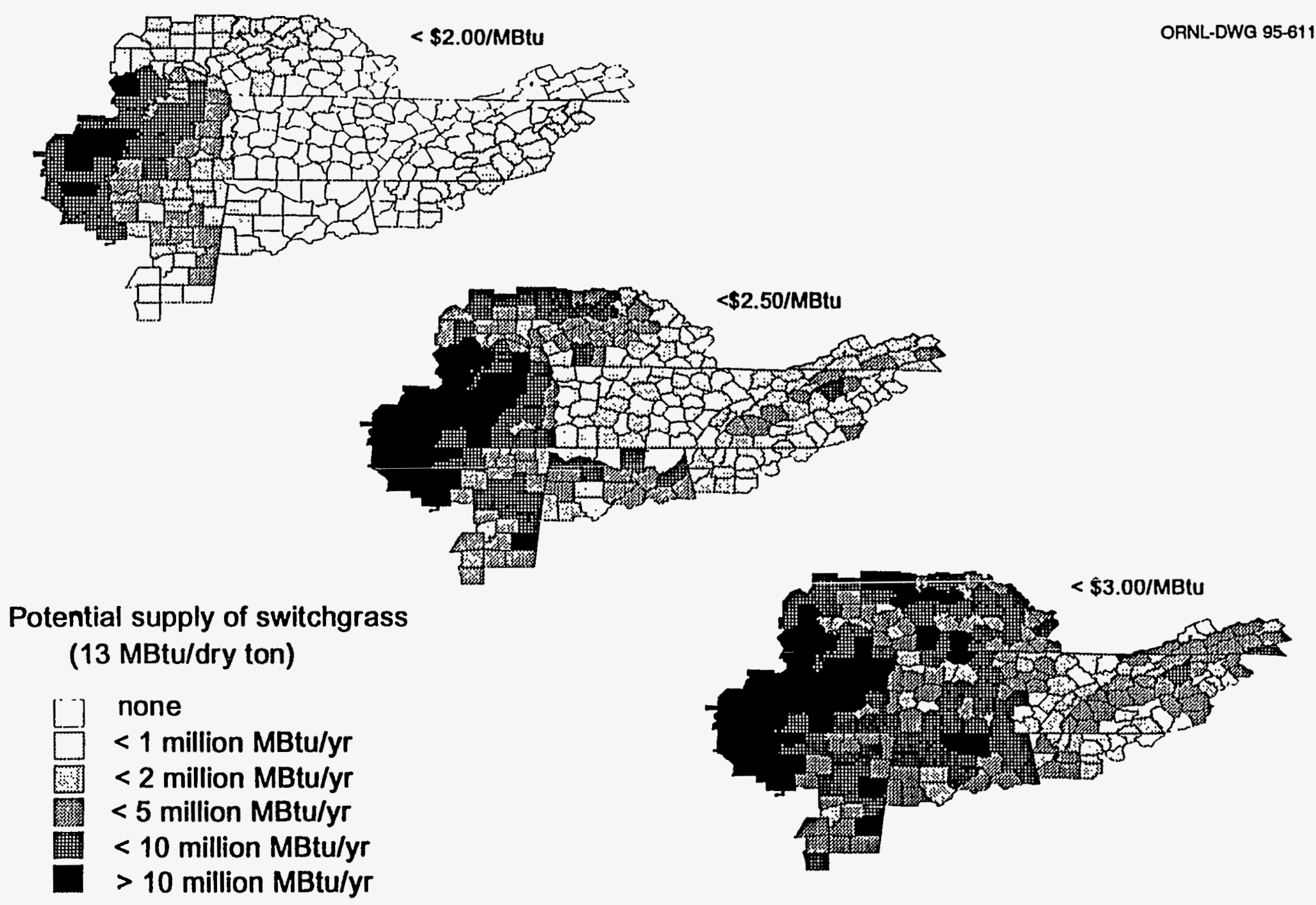

Fig. 7. Amount of switchgrass feedstock (in MBtu) that could potentially be produced in the TVA region counties at a farm-gate price of less than $\$ 200 / \mathrm{MBtu}$, less than $\$ 2.50 / \mathrm{MBtu}$, and less than $\$ 3.00 / \mathrm{MBtu}$ if current switchgrass yields were increased $25 \%$. The farm-gate price does not include transportation cost. 
ORNL-DWG 95-6116

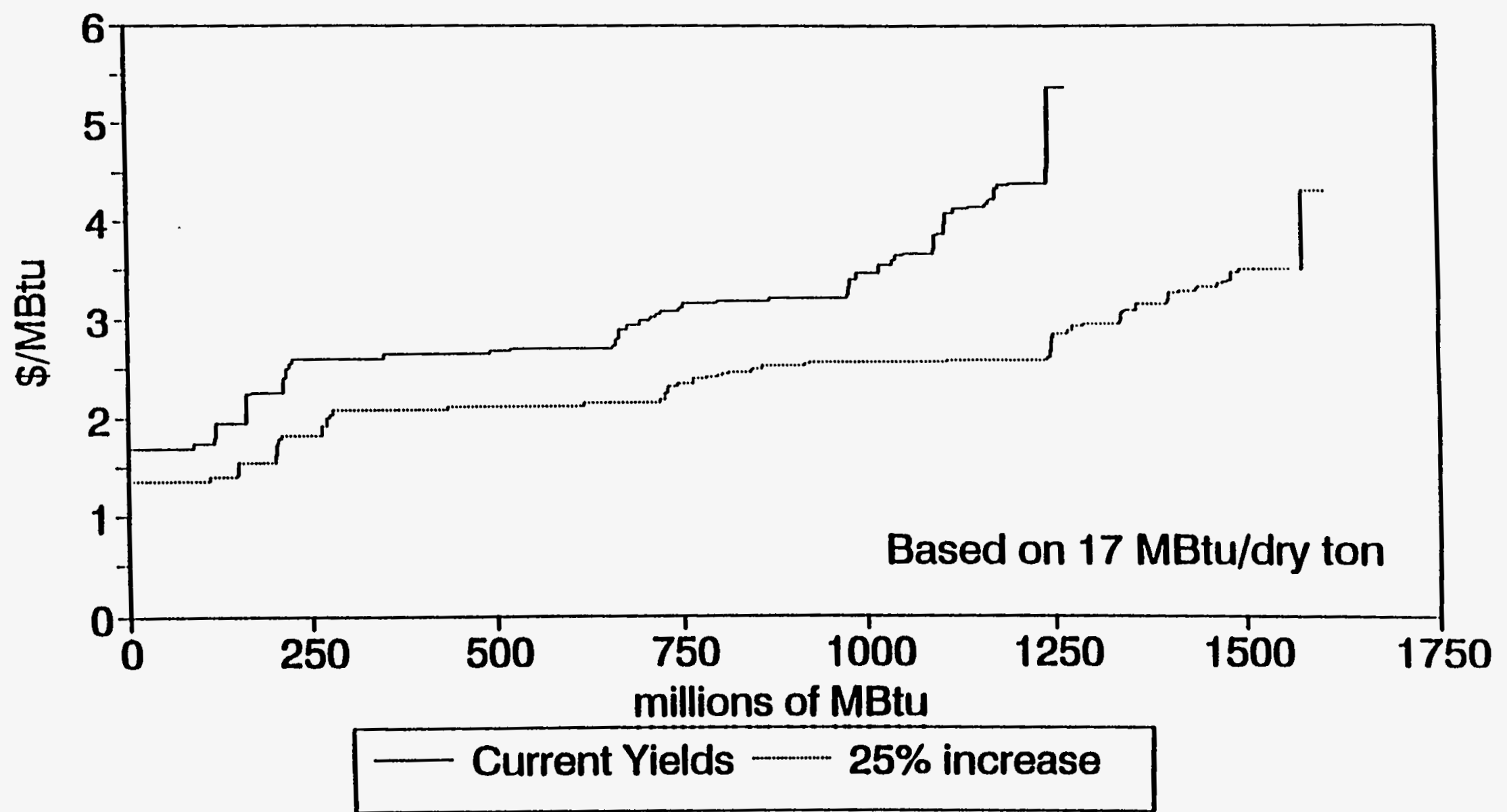

Fig. 8. Regionwide supply curves for SRWC wood feedstock in units of energy (MBtu), assuming current yield and 25\% increased yield. 
ORNL-DWO 95-6117

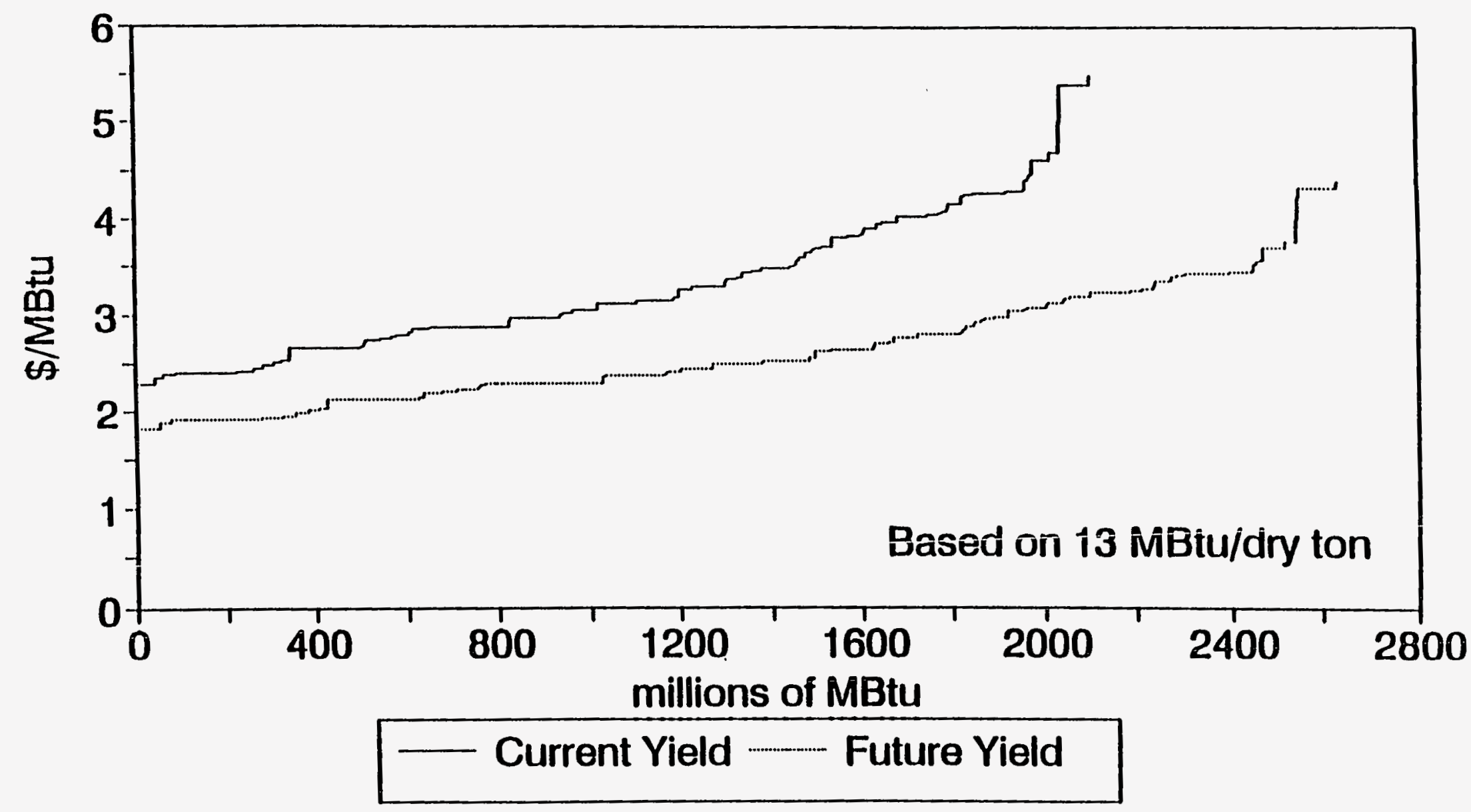

Fig. 9. Regionwide supply curves for switchgrass feedstock in units of energy (MBtu), assuming current yield and $25 \%$ increased yield. 
region can produce $1.26 \times 10^{9} \mathrm{MBtu}$ of SRWC wood or $2.08 \times 10^{9} \mathrm{MBtu}$ of switchgrass. Increasing energy crop yields per acre by $25 \%$ increases total potential by supply $25 \%$ and lowers the price of the supply by nearly $20 \%$. Figures 10 and 11 show the same supply curves in $\$ /($ dry) ton and millions of (dry) tons of biomass. 
ORNL-DWG 95-6118

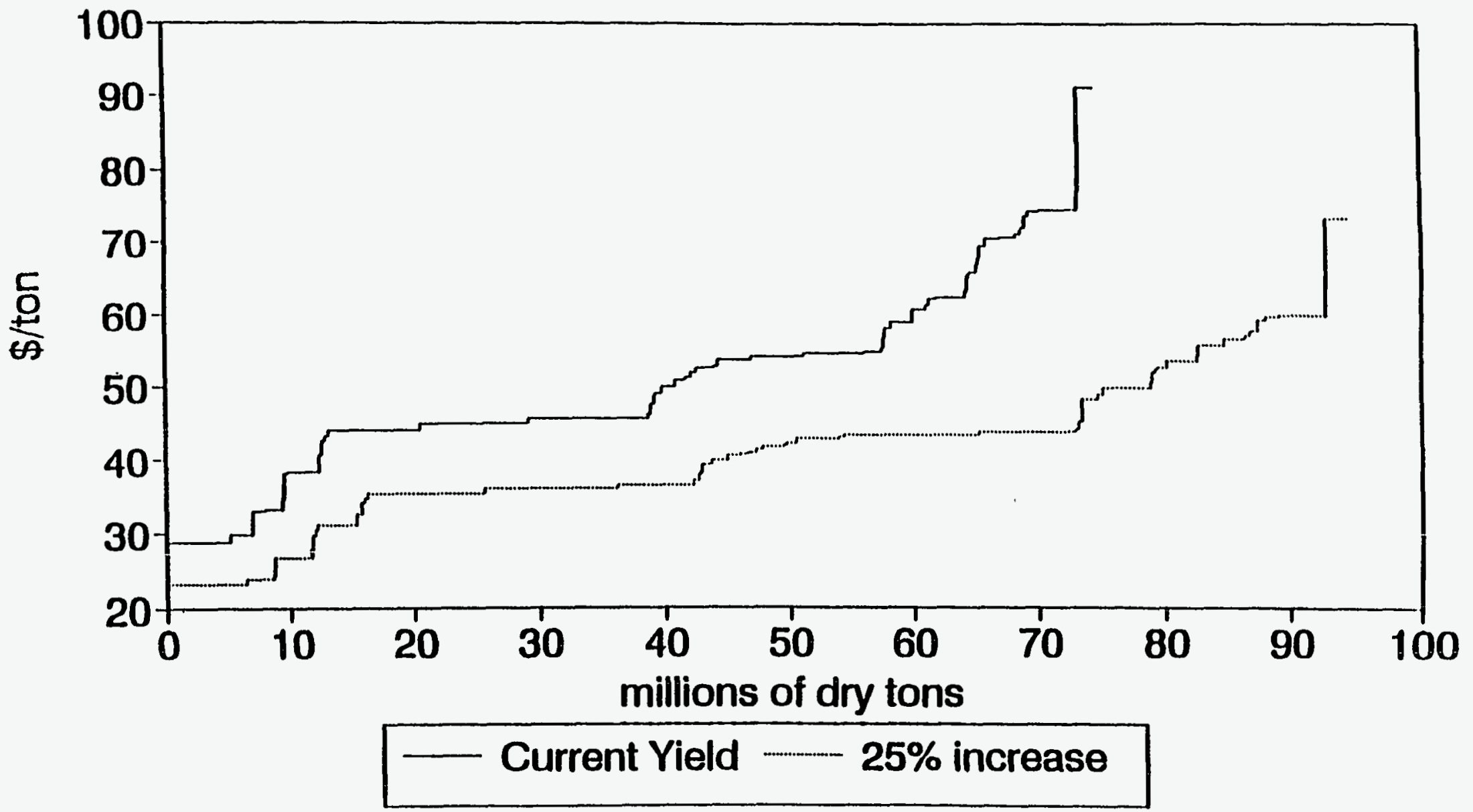

Fig. 10. Regionwide supply curves for SRWC wood feedstock in units of biomass (tons), assuming current yield and 25\% increased yield. 
ORNL-DWG 95-6119

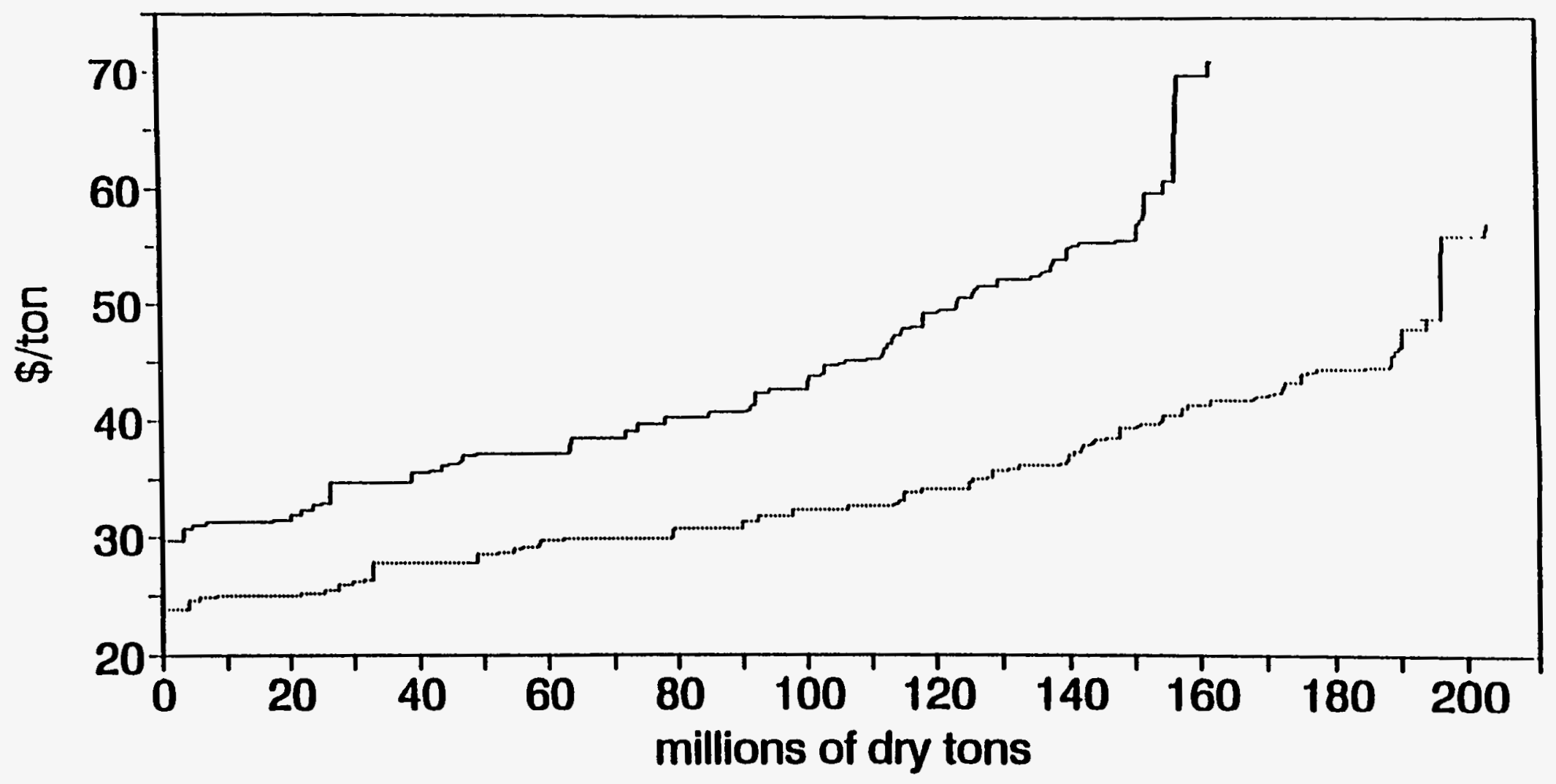

Fig. 11. Regionwide supply curves for switchgrass feedstock in units of biomass (tons), assuming current yield and $25 \%$ increased yield. 


\section{CONCLUSIONS}

Agricultural land in the TVA region can potentially support $18 \mathrm{GW}$ if wood is the sole fuel and $30 \mathrm{GW}$ if switchgrass is the sole fuel. (This projection assumes an efficiency of 10,000 Btu of biomass per kilowatt hour, an efficiency achievable with existing technology.) Farm-gate prices in the range of $\$ 40$ to $\$ 50$ per ton for wood or $\$ 35$ to $\$ 45$ per ton for switchgrass are needed to ensure landowners of profits commensurate with current land use. Although switchgrass farm-gate prices are lower than those of SRWC, switchgrass is a slightly more expensive fuel because of its lower energy content.

From a regional perspective, energy crop supplies are projected to be greatest in the western portion of the region, largely because of the high density of agricultural land combined with low land rents. However, there are clusters of counties elsewhere that can produce supplies sufficient to support production of 100 or $200 \mathrm{MW}$ of power.

This is a regional analysis of potential biomass supplies. Caution is required when interpreting the study results at the county scale because of the aggregation and generalization used in the analysis. In particular, the definition of subregion boundaries play a critical role in determining the spatial pattern of biomass supplies. For energy crop demonstration or individual plant site studies, the approach developed in this regional analysis can be used if finer and more localized data on soils, land use, and crops were used. 


\section{REFERENCES}

Bransby, D. I., S. E. Sladden, and D. D. Kee. 1990. Selection and improvement of herbaceous energy crops for the southeastern United States: Final report on a field and laboratory research program for the period March 15, 1985 to March 14, 1990.

ORNL/Sub/85-27409/5. Oak Ridge National Laboratory.

Graham, R. L., B. C. English, R. R. Alexander, and M. G. Bhat. 1992. Biomass Fuel Costs Predicted for an East Tennessee Power'Plant. Biologue 10:23-26.

Johnson, L. A. 1990. Guide to Farm Planning. Agricultural Extension Service EC622, The University of Tennessee.

Noon, C. E. 1993. TVA GIS-based biomass resource assessment. pp. 74-78. In Proceedings of the First Biomass Conference of the Americas. National Renewable Energy Laboratory, Golden Co.

Office of Technology Assessment (OTA). 1980. Energy From Biological Processes, Vol 1.

Parrish, D. J., D. D. Wolf, W. L. Daniels, D. H. Vaughn, and J. S. Cundiff. 1990. Perennial species for optimum production of herbaceous biomass in the Piedmont: Final report 1985-1989. ORNL/Sub/85-27413/5. Oak Ridge National Laboratory.

Sharpley, A. N., and J. R. Williams, eds. 1990. EPIC-Erosion Productivity Impact Calculator: 1) Model Documentation. Technical Bulletin No. 1768. United States Department of Agriculture, Washington, D.C.

Soil Conservation Service. 1984. 1982 National Resources Inventory. Data Tape, United States Department of Agriculture, Washington, D.C.

U.S. Department of Agriculture. 1990. Economic Research Service, Report 261-420:20375. U.S. Government Printing Office, Washington, D.C.

U.S. Department of Agriculture. 1989. National Agricultural Statistics: County Crop Estimates. Data Diskettes, Washington, D.C. 
U.S. Department of Agriculture. 1988. National Agricultural Statistics: County Crop Estimates. Data Diskettes, Washington, D.C.

U.S. Department of Agriculture. 1981. Land Resource Regions and Major Land Resource Areas of the United States. Agricultural Handbook No. 296. U.S. Department of Agriculture Soil Conservation Service, Washington, D.C.

U.S. Department of Commerce. 1989. 1987 Census of Agriculture, Vol. 1, Geographic Area Series. Bureau of the Census, U.S. Government Printing Office, Washington, D.C.

Wright, L. L., R. L. Graham, A. F. Turhollow, and B. C. English. 1992a. Growing Shortrotation Woody Crops for Energy Production. pp. 97-122. In R. N. Neil and D. Hair (eds.), Forests and Global Change, Vol. 1: Opportunities for Increasing Forest Cover, Washington, D.C.: American Forests.

Wright, L. L., J. H. Cushman, A. R. Ehrenshaft, S. B. McLaughlin, W. A. McNabb, J. W. Ranney, G. A. Tuskan, and A. F. Turhollow. 1992b. Biofuels feedstock development program progress report for 1991. ORNL-6742. Oak Ridge National Laboratory. 